\title{
Present-day stress field pattern in the Vrancea seismic zone (Romania) deduced from earthquake focal mechanism inversion
}

\author{
Andrei Bala ${ }^{1}$, Mircea Raduliann ${ }^{1,2,3}$, Dragos Toma-Danila*,1 \\ (1) National Institute for Earth Physics, Magurele, Ilfov, Romania \\ (2) Academy of Romanian Scientists, Bucharest, Romania \\ (3) Romanian Academy, Bucharest, Romania
}

Article history: received January 24, 2021; accepted October 12, 2021

\begin{abstract}
Vrancea seismogenic zone in the South-Eastern Carpathians is characterized by localized intermediate-depth seismicity. Due to its complex geodynamics and large strain release, Vrancea represents a key element in the Carpatho-Pannonian system. Data from a recently compiled catalogue of fault plane solutions (REFMC) are inverted to evaluate stress regime in Vrancea on depth. A single predominant downdip extensive regime is obtained in all considered clusters, including the crustal layers located above the Vrancea slab. The prevalent stress regime confirms previous investigations and requires some mantle-crust coupling. The $S_{3}$ principal stress is close to vertical, while $\mathbf{S}_{1}$ and $\mathbf{S}_{2}$ are horizontal, oriented perpendicularly and respectively tangentially to the Carpathians Arc bend. This configuration is present at any depth level. According to seismicity patterns, there are two main active segments in the Vrancea intermediate-depth domain, at 55 - 105 $\mathrm{km}$ and $105-180 \mathrm{~km}$, both able to generate major events. The configuration of the tectonic stresses as resulted from inversion is similar in both segments. Also, high fault instability $(\mathrm{I}>0.95)$ is characterizing the segments. The only notable difference is given by the friction and stress ratio parameters which drop down in the bottom segment from $\mu=0.95$ to $\mu=0.55$ and from $\mathrm{R}=0.51$ to $\mathrm{R}=0.29$. This variation is attributed to possible weakening processes activated below $100 \mathrm{~km}$ depth and can explain the intensification of seismicity production as earthquake rate and average energy release in the lower segment versus the upper segment.
\end{abstract}

Keywords: Tectonic stress; Focal mechanism; Earthquake; Vrancea; Seismicity.

\section{Introduction}

There are a few areas in the world characterized by localized intermediate-depth seismic activity where earthquakes are generated in subducted lithosphere far from the plate boundaries [Prieto et al., 2012]. Among these we mention Bucaramanga (Colombia), Hindu Kush (Afghanistan) and Vrancea (Romania). In Vrancea, earthquakes of moment-magnitude $\left(\mathrm{M}_{\mathrm{w}}\right)$ up to 7.9 (INFP, 2020) occur in an almost vertically oriented lithosphere body from around $60 \mathrm{~km}$ to around $180 \mathrm{~km}$ depth (Figures 1 and 2). In the framework of the South-Eastern Carpathians 


\section{Andrei Bala et al.}

geodynamic system, the Vrancea seismic region, located in the area of curvature of the mountain range, is a key area to decipher, especially since major earthquakes occurring here can affect a wide-spread region - around half of Romania but also northern Bulgaria and Republic of Moldova [Pavel et al., 2016]. Tectonically, Vrancea is situated at the contact of multiple tectonic units: East European platform to the north and north-east, Scythian Platform to the east, North-Dobrogean orogen to the south-east, Moesian platform to south and south-west, Carpathians orogen and Transylvanian basin to north-west (Figure 1).

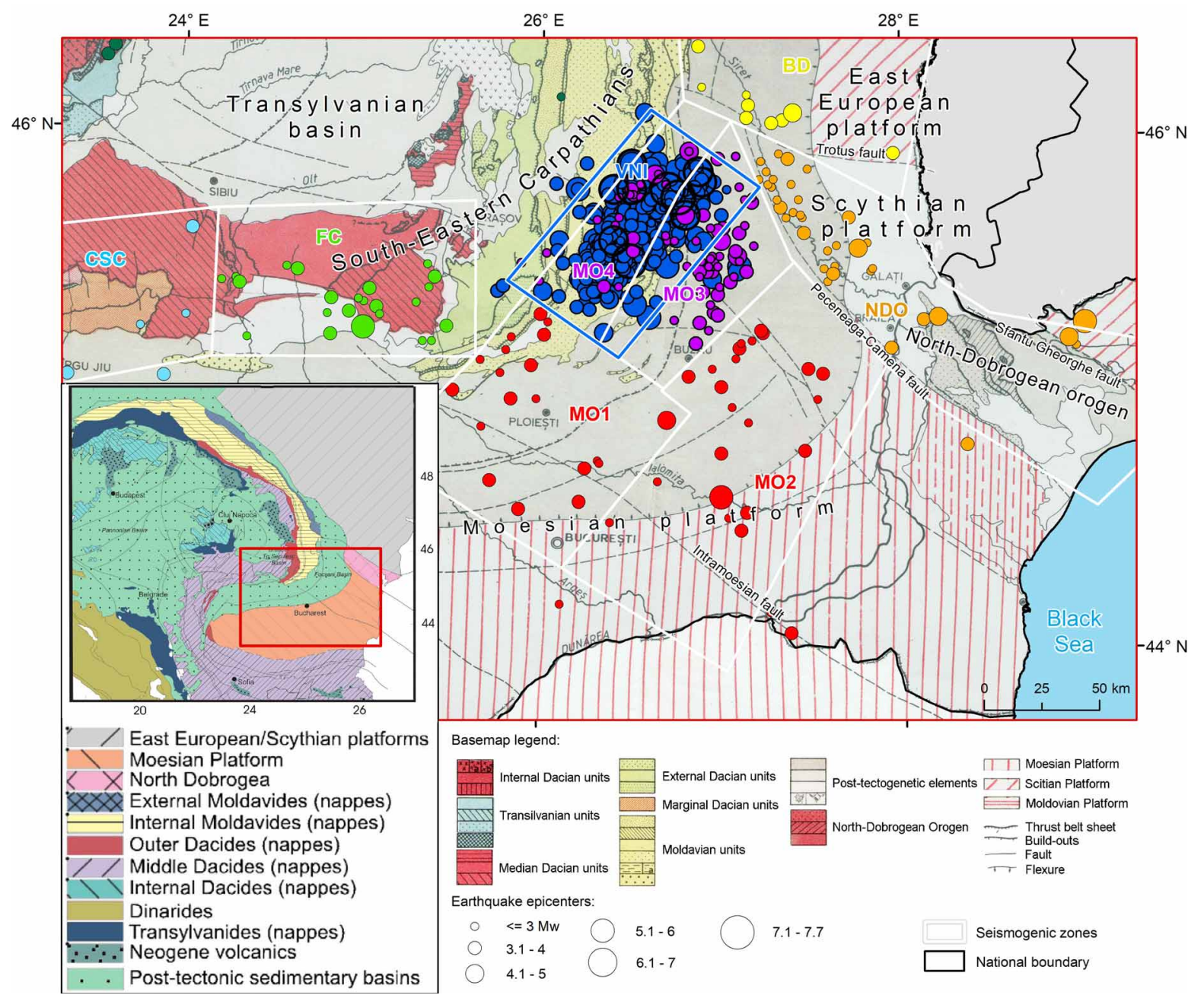

Figure 1. Seismogenic zones defined as polygons in the frame of tectonic settings after Săndulescu [1984] in the area of South-Eastern Carpathians arc bend. The circles are colored according to the zone (as classified in Bala et al, 2019) and size is proportional with magnitude. Abbreviations: VNI - Vrancea intermediate zone; NDO - North Dobrogean orogen zone; BD - Bârlad depression zone; MO1 - MO4 - subzones of Moesian platform zone; FC Făgăraș Câmpulung zone, CSC - Central South Carpathians. The drawing order for Vrancea Area is: all VNI earthquakes on bottom, MO4 and MO3 in the middle and the black outline circle of VNI earthquake with Mw $\geq$ 6.1 on top. The inset shows the general tectonic setting and is based on Bocin et al. [2013].

Active collision in Carpathians ended about 9 Ma ago [Matenco et al., 2010]. Since then, specific tectonic processes took place, such as subsidence in the Carpathians foreland and magmatic activity in the inner side of the Carpathians, still active at present [Szakács and Seghedi, 2013]. The migration of depocenters towards the foreland and of the volcanism southwards along the inner side of the Carpathians are most probably related to evolution in time and space of the continuous gravitational pull exerted by the Vrancea sub-crustal high-velocity body. 
The seismicity and stress data are key elements to understand the present-day dynamics of the tectonic system in the Vrancea area.

The anomalous high-velocity body beneath Vrancea is clearly visible in the tomographic images both from teleseismic and local waveforms [Wortel and Spakman, 2000; Martin et al., 2006; Koulakov et al., 2010]. Its highvelocity volume is significantly larger than the seismically active range [Martin et al., 2006]. There is no consensus about the origin of the body - whether it is a piece of the relic continental lithosphere or a relic of oceanic slab and hence about the type of geodynamic processes taking place in the region descending oceanic slab, slab detachment or delamination of the continental lithosphere [for a review of various models of geodynamics and seismicity in Vrancea, see Ismail-Zadeh et al., 2012].

From a seismic point of view, the coupling between the activity in the subducted lithosphere and crust is weak, with a dispersed and weak seismicity at the transition between the subducted lithosphere and overlying crust. In the deepest sector of the earthquake-prone volume the seismicity is strongly cut off below $180 \mathrm{~km}$ depth. Epicentral area is elongated from NE to SW over about $70 \mathrm{~km}$ distance, whereas the hypocenters deepen toward SW (Figure 2).

It is interesting to note that the fault plane solutions are fitting well the geometrical features of the seismic

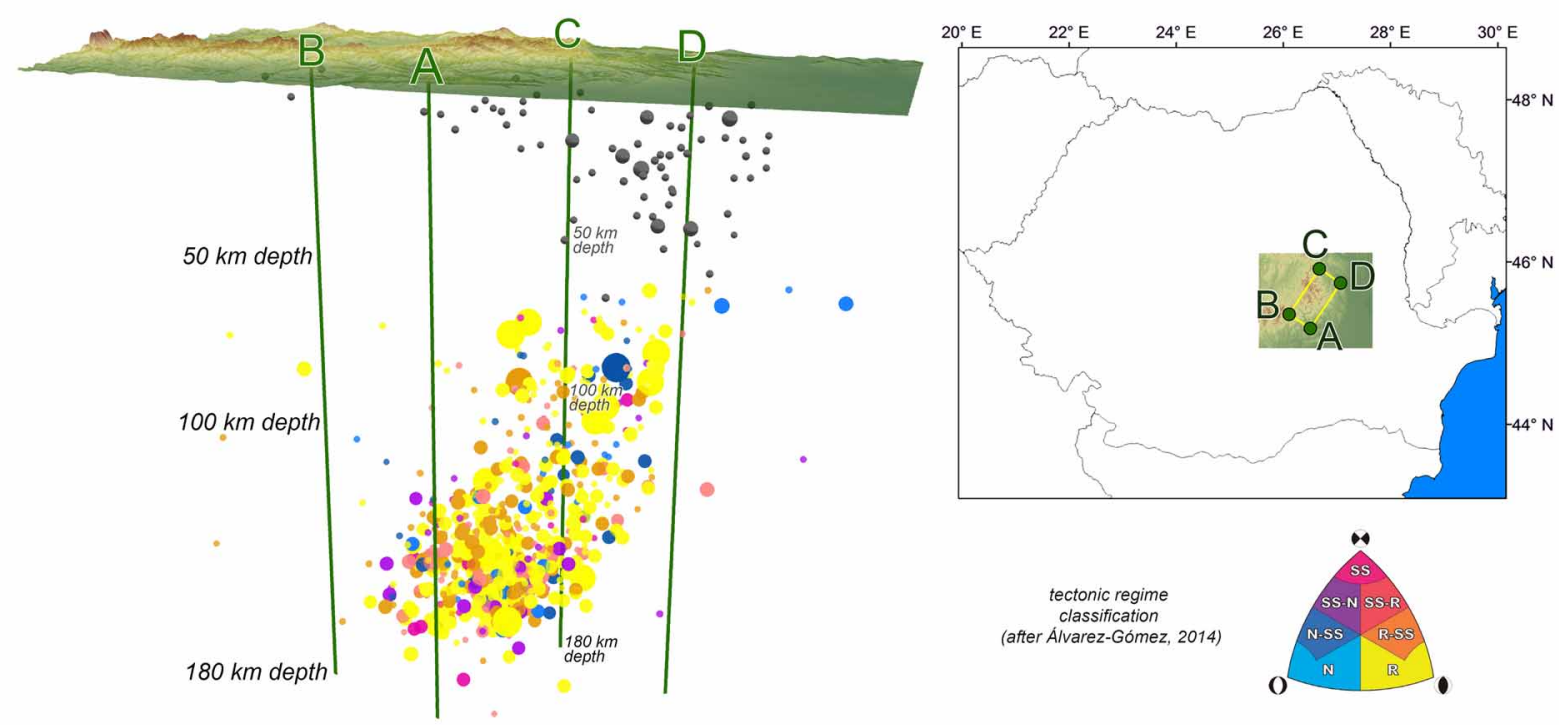

Figure 2. The mechanisms of VNI. Events are represented by circles with the size corresponding with magnitude Mw and the color to the tectonic regime classification in the ternary diagram [after Álvarez-Gómez, 2019]. Only events with more than 20 reliable polarities are represented.

activity. The nodal plane that is most likely the rupture plane is plunging close to vertical and is oriented NE-SW, the same orientation as the seismicity. Most of the solutions are of reverse type with the extension axis close to vertical. The fault-plane solutions for the last major Vrancea earthquakes (the ones in 1940, 1977, 1986 and 1990 with $\mathrm{M}_{\mathrm{w}} \geq 6.9$ ) all show these features [Radulian, 2014]. The nodal plane considered as rupture plane (on the basis of aftershock activity) is close to vertical, slightly plunging toward NW (to the Transylvanian basin). Early studies pointed out that most of the Vrancea intermediate-depth earthquakes are following this pattern regardless of magnitude [Enescu, 1980; Oncescu 1987; Oncescu and Trifu, 1987]. Later on, some variability of the fault-plane solutions is also recorded [Enescu and Enescu, 1998; Radulian et al., 2019].

Some studies, based on detailed and refined seismicity pattern analysis, suggest the existence of two predominant alignments, both oriented tangent to the Carpathians Arc (NE-SW), but with a small ( $\sim \mathrm{km})$ relative displacement around $100 \mathrm{~km}$ depth [Ganas et al., 2010; Cărbunar et al., 2011]. The two alignments are associated with two relative independent earthquake-prone segments, situated in two depth domains, separated by a sort of transition zone around $100 \mathrm{~km}$ depth, which marks a change in seismicity and most probably in the geotectonics, whose nature is still non elucidated. A matter worth to be investigated is the variability of the focal mechanism 


\section{Andrei Bala et al.}

and stress field along the vertical seismically active body beneath the Vrancea region, in correlation with the possible seismicity segmentation. A few investigations were performed on this subject [Oncescu and Trifu, 1987; Oncescu and Bonjer, 1997], but using a reduced amount of data.

The purpose of the present study is to employ a comprehensive set of fault-plane solutions available for the Vrancea intermediate-depth and crustal earthquakes [Bala et al., 2019] in order to emphasize the stress characteristics in the subducted lithosphere and overlying crust in connection with the geodynamic processes responsible for generating the seismicity at the South-Eastern Carpathians Arc bend. The dataset comprising of a catalogue of fault-plane for the earthquakes recorded between 1929 and 2012 [Radulian et al., 2018; 2019] called REFMC [Radulian et al., 2020] is much better represented both in number of events and quality (considering the number of stations used but also in some cases the method of determination), comparatively with previous investigations [Radulian et al., 2000; Radulian et al., 2002]. The improved data allow us to estimate the stress within the earthquake-prone descending body and in the overlying crust by inverting focal mechanism data in order to find the horizontal stress and to explore its distribution in depth.

\section{Fault plane solutions data and selected groups}

A catalogue of fault plane solutions for earthquakes recorded in Romania between 1929 and 2012 was compiled from the catalogues previously published by Radulian et al. [2018] for the time interval 1998 - 2012 and Radulian et al. [2019] for the time interval 1929 - 2000. The contiguous catalogue of fault plane solutions $(1929-2012)$ is analyzed and presented in Bala et al. [2019] separated in two groups: the intermediate-depth earthquakes occurring in Vrancea zone (VNI) at depths $\geq 50 \mathrm{~km}$ and the crustal earthquakes at depths $<50 \mathrm{~km}$ located above the subcrustal source, mostly in the southern part of Romania (Figure 1). An analysis focused on the fault-plane solutions of the events and inversion of focal mechanism for the determination of the horizontal stress in the crust on Romanian territory was carried out by Bala et al. [2020]; this however does not provide many details regarding the special setting of the Vrancea zone.

The epicenters of the events in the catalogue located in the Vrancea and in the extra-Carpathian area are plotted in Figure 1. The subcrustal earthquakes are represented with blue symbols, while the overlying crustal earthquakes are represented by magenta symbols. The other seismogenic sources belonging to Moesian platform (MO1, MO2), North Dobrogea orogen (NDO), Bârlad depression (BD) and Făgăraş - Câmpulung (FC) are considered and analyzed by Bala et al. [2020] together with all other crustal events in Romania. The definition and the abbreviated names of the zones were taken from Bala et al. [2019]. The seismicity in the largest part of the eastern Moesian platform (MO1, MO2) is weak, while to the west of Argeş river, it is almost missing; the only exception is the zone located close to the epicentral area of the Vrancea intermediate-depth earthquakes (MO3 and MO4) which is likely to be in connection with the geodynamics in the mantle. The earthquakes generated here had $\mathrm{M}_{\mathrm{w}}<5.5$ and many times they occurred in sequences, especially towards SE of Vrancea, in MO3 [Popescu and Radulian, 2001]. Note also that these sequences follow an alignment NE-SW, which resembles the similar alignment observed for the deep events [Popescu and Radulian, 2001; Popescu et al., 2011; Raileanu et al., 2009]. The seismic activity in NDO is clustered along the major faults crossing the region from Black Sea to the Carpathians (Peceneaga-Camena and Sf. Gheorghe faults). The seismicity is more diffuse in $\mathrm{BD}$ and $\mathrm{FC}$. Five shocks of $\mathrm{M}_{\mathrm{W}}$ between 6.2 and 6.5 were recorded in $\mathrm{FC}$ since $\mathrm{XVI}^{\mathrm{th}}$ century. In order to invert the fault plane solutions for stress determination we consider two groups of events, first in the slab sinking in the mantle and second in the crust surrounding the Vrancea zone, groups which are investigated separately.

We focus our attention in this work on the seismic activity closely related to the Vrancea zone (study area is simply defined in Figures 2 and 3 as the polygon $A B C D$ ). For this we use focal mechanisms of 634 intermediate-depth events with $M_{w}$ between 2.6 and 7.7 and 74 crustal events with $M_{w}$ between 2.1 and 4.6 which occurred in the 1929 - 2012 period. The 3-D representation of the hypocenter distribution for the events with reliable focal mechanism (at least 20 well-defined first P-wave polarities) shows interesting and characteristic features (Figure 2): a clear discrepancy as concerns the energy release and clustering degree between the subducted lithosphere and crustal earthquakes, a relative deficit of earthquakes in the transition layer between crust and subducted lithosphere, a predominant reverse faulting regime in the slab (the same regime can be noticed in the crust as well, but less pronounced). A change is visible in the seismicity regime between the upper segment of the Vrancea seismogenic volume (noted below as VNI_A) and the lower segment (noted below as VNI_B). 


\section{Stress field pattern in the Vrancea zone}

Ternary diagrams are plotting the plunge of the intermediate (B) and tension axes (T) of focal mechanisms to illustrate the faulting style of the seismotectonic regimes. The plotting method, as proposed by Álvarez-Gómez [2019] using the FMC script which improves the ternary diagrams of Kaverina et al. [1996], was already used to characterize the faulting style in the crust in the southern Romania by Bala et al. [2019]. Note that the ternary diagrams do not reflect fault orientation, which is an additional criterion for the delineation of the seismotectonic domains [Pondrelli and Morelli, 2008].

In order to apply the inversion of focal mechanism data to evaluate the stress regime, we subdivided the seismogenic volume into different cell zones sufficiently large to include minimum 30 events with computed fault plane solutions, as suggested by Vavryčuk [2014]. The partition for VNI is made following mainly the particular geometry of the seismogenic volume. As such, we defined parallelepiped-like cells of $35 \times 25 \times 25 \mathrm{~km}$ dimensions, in $\mathrm{NE}, \mathrm{SE}$, and vertical directions, respectively. In this way, we fit the shape of the projection the Vrancea earthquakeprone volume, which is an approximate rectangle of 70-75 km length per 25-30 km width (Figure 3), by 3 cells. Also, the entire depth range $(55-180 \mathrm{~km})$ is fitted within 5 layers, being able to capture the hypocenter transition with depth as reflected by Figure 2. The cell dimensions are also conventionally selected such as to have regular cells fitting the Vrancea earthquake-prone volume and to include in each of them at least 30 earthquakes.

The focal mechanisms for the earthquakes occurring in the crustal seismic zones located directly above VNI (MO4 and MO3) are also examined in order to compare the horizontal stress computed in the subducted lithosphere with that in the overlying crust. For the crustal earthquakes, we used single cells per seismogenic area, as shown in Figure 3. MO4 is practically overlapping the epicentral area of the Vrancea subcrustal earthquakes, while for MO3 a non-regular shape is adopted so that to cover as much as possible the seismicity pattern. With the partition specified in this way, the repartition of the total number of earthquakes with focal mechanism computed (634 events) in VNI is that of Table 1.

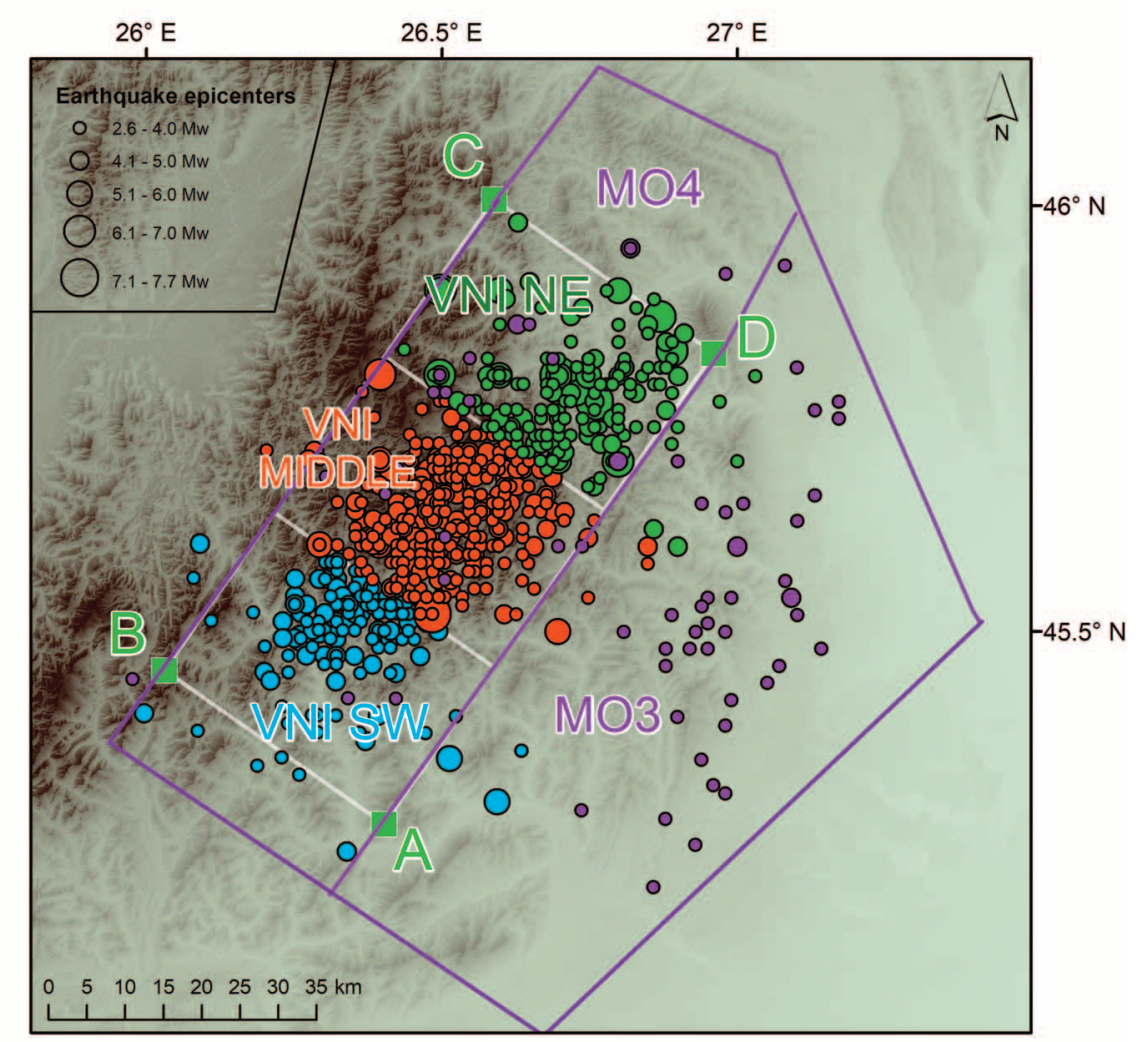

Figure 3. Events in the Vrancea intermediate-depth zone (VNI: 55 - $180 \mathrm{~km}$ depth) projected at surface, in order to reflect the cell clusters in latitude and longitude in which they were separated: VNI NE, VNI middle and VNI SW; these cell clusters can be seen also in 3D in Figure 2 (with A, B, C and D points as reference) and in Figure 6; crustal zones MO3 and MO4 (1 - 50 km depth) and corresponding earthquakes can also be seen in purple. 


\section{Andrei Bala et al.}

\section{Methodology}

Several methods have been developed to determine stress field by inversion of earthquake focal mechanisms. Michael [1984], Gephart [1990], Angelier [2002] contributed to the development of these techniques. These methods usually assume that, for optimum results, a few main conditions should be fulfilled:

- tectonic stress is homogeneous in the region;

- earthquakes occur on pre-existing faults with varying orientations;

- the slip on a fault occurs in the direction of maximum shear stress, the so-called Wallace-Bott hypothesis [see Wallace, 1951; Bott, 1959];

- the earthquakes do not interact with each other and do not disturb the background tectonic stress.

Vavryčuk [2014] developed these technique into an algorithm called StressInverse, following the conditions above.

Obviously, these conditions are not entirely satisfied in our case, taking into account that we employ for inversion data from earthquakes with foci spread from near surface down to $180 \mathrm{~km}$ depth.

When stress is not uniform over the entire study region, we subdivide it into smaller areas for which the condition of uniform tectonic stress is more easily satisfied. The way is to define subzones as small as possible but containing at the same time a reasonable number of earthquakes (no less than 30 events) (see Table 1 and Figure 3).

The Wallace-Bott assumption of the slip vector parallel to the stress on the fault is valid only in isotropic media. In anisotropic media, the two vectors are not necessarily parallel and the problem becomes more complicated, particularly when the knowledge of the anisotropy in the focal zone is difficult, which happen to be our case, mostly due to the depth of the hypocenters.

Stress changes due to the occurrence of small and moderate earthquakes are usually negligible, but large earthquakes can significantly affect the background stress field. From this point of view, it is ideally to perform the inversion for earthquakes clustered not only in space but also in time, separately for time intervals between large earthquakes, and after them. For the time being, the dataset available cannot ensure sufficient statistics to obtain a good accuracy of the results on distinct time intervals.

The software StressInverse is applied to estimate the stress tensor. This software is based on Michael's method [Michael, 1984] and incorporates the instability criterion proposed by Lund and Slunga [1999]. It represents a linear, iterative stress inversion based on the four assumptions presented above. Although these assumptions look apparently very restrictive, the analysis of real observations proves that they are well-satisfied in most cases, in particular, for local seismicity consisting of weak to moderate earthquakes (Gorgun et al., 2016; Fojtíková and Vavryčuk, 2018). Details about the method and its accuracy are published in Vavryčuk [2014].

The method proposed by Michael [1987] was developed in several stress inversion codes such as SATSI [Hardebeck and Michael, 2006] and MSATSI developed in MATLAB [Martinez-Garzon et al., 2014], for the appropriate calculation of the horizontal stresses. The extensive description of MSATSI, which we used in this study, is presented along with examples in Martínez-Garzón et al. [2014].

The inversion outcome comprises the orientation of the principal stress axes $\left(\mathbf{S}_{1}, \mathbf{S}_{2}, \mathbf{S}_{3}\right)$ and the stress ratio (R):

$$
\mathrm{R}=\left(\sigma_{1}-\sigma_{2}\right) /\left(\sigma_{1}-\sigma_{3}\right)
$$

where $\sigma_{1}, \sigma_{2}, \sigma_{3}\left(\sigma_{1}>\sigma_{2}>\sigma_{3}\right)$ are the eigenvalues of the stress tensor and $0<\mathrm{R}<1$.

Both StressInverse and MSATSI algorithms use the same definition of stress ratio $\mathrm{R}$ as the one in Equation 1 [see also Vavrickuk, 2014; Martinez Garzon et al., 2014; 2015].

The estimation of errors is provided by a repeated stress inversion of focal mechanisms contaminated by artificial noise. In StressInverse the uncertainties are computed as the maximum differences between the results of the inversion for noise-free and noisy data after 1000 noise realizations. This method proves to be more convenient for two reasons: first, it takes into account the case when some nodal planes are more uncertain than the others by specifying differently noise levels for the fault orientations and slip directions. Second, the uncertainties are obtained in a narrow domain. For example, the shape ratio $\mathrm{R}$ computed by iterative method has uncertainties between $6-12 \%$ as opposed to those obtained by Michael's method of 20 - 44\% [Vavryčuk, 2014]. For this study we 
used 100 realizations of random noise in the inversion. The level of noise of $10^{\circ}-12^{\circ}$ corresponds to the estimated accuracy of input focal mechanisms. The inversion process is usually stopped after 5 iterations.

MSATSI is useful as the results can be considered and presented as 1D, 2D or 3D models in some arbitrary cells. A scheme of damping can be employed between two successive cells in order to smooth the transition of the stress direction from one cell to the next. However, when analyzing real data sets, the uncertainties of the retrieved stress directions, the shape ratio, the fault selection and overall friction on faults are calculated by the bootstrap method as proposed by Michael [1987].

In a recent study about the results obtained with MSATSI, Martinez-Garzón et al. [2016] consider that, if the focal mechanisms sufficiently cover the range of allowed orientations within an ambient stress field with a stress ratio $\mathrm{R}$ $=0.5$, at least 20 mechanisms are necessary to resolve the stress field orientation with low noise conditions, while at least 40 are necessary for data sets with high noise. In our case we have employed cells defined so that to include at least 30 events with computed mechanism (in eight out of ten cells we have more than 40 events - see Table 1).

\begin{tabular}{|c|c|c|c|c|c|c|}
\hline VNI layer & $\begin{array}{c}\text { Arbitrary } \\
\text { coord used in } \\
\text { the MSATSI } \\
\text { software } \mathrm{X} / \mathrm{Y} / \mathrm{Z}\end{array}$ & $\begin{array}{c}\text { Depth } \\
(\mathbf{K m})\end{array}$ & VNI NE & VNI Middle & VNI SW & Total \\
\hline VNI1 & & $55-80$ & 26 & 6 & 3 & 35 \\
\hline $\mathrm{C} 1$ & $3 / 3 / 4$ & & 35 & & & \\
\hline VNI2 & & $81-105$ & 56 & 36 & 1 & 93 \\
\hline $\mathrm{C} 2$ & $3 / 3 / 3$ & & 56 & & & \\
\hline $\mathrm{C} 3$ & $2 / 2 / 3$ & & & 37 & & \\
\hline VNI3 & & $106-130$ & 52 & 80 & 40 & 172 \\
\hline $\mathrm{C} 4$ & $3 / 3 / 2$ & & 52 & & & \\
\hline $\mathrm{C} 5$ & $2 / 2 / 2$ & & & 80 & & \\
\hline C6 & $1 / 1 / 2$ & & & & 40 & \\
\hline VNI4 & & 131- 155 & 39 & 167 & 79 & 285 \\
\hline $\mathrm{C} 7$ & $3 / 3 / 1$ & & 39 & & & \\
\hline $\mathrm{C} 8$ & $2 / 2 / 1$ & & & 167 & & \\
\hline C9 & $1 / 1 / 1$ & & & & 79 & \\
\hline VNI5 & & $156-180$ & 5 & 32 & 12 & 49 \\
\hline C10 & $2 / 2 / 0$ & & & 49 & & \\
\hline TOTAL & & & & & & 634 \\
\hline
\end{tabular}

Table 1. Distribution in depth of the intermediate-depth earthquakes (1929 - 2012) with reliable fault plane solutions, considered in the present paper (Figure 3); when a cell does not contain at least 30 events, we associate it to one or two neighboring cells in the same layer (like C1 in VNI1).

\section{Results}

In order to apply inversion procedure, we set the partition of VNI following three rules: using regular cells, following the particular geometric configuration of the Vrancea seismogenic volume and including almost all the Vrancea intermediate-depth earthquakes (Table 1 and Figure 3). Thus, the approximate NE-SW oriented rectangle shape (70-75 km long per $25-30 \mathrm{~km}$ width) of the epicentral distribution is well covered by three cells $\left(25 \times 35 \mathrm{~km}^{2}\right)$, while the intermediate-depth interval ( $55 \mathrm{~km}$ to $180 \mathrm{~km}$ depth) is encompassed by five layers VNI1 - VNI5 of $25 \mathrm{~km}$ thickness each. For the crustal domain we consider two zones in a single layer of $50 \mathrm{~km}$ thickness (MO3-MO4): MO4 roughly overlapping the epicentral area of the intermediate-depth earthquakes and MO3 of non-rectangular shape, adjacent to this area. 


\section{Andrei Bala et al.}

The StressInverse algorithm does not require that the events be located in a certain cell. In order to compare the results obtained by inversion using StressInverse and MSATSI algorithms we carried out the computations following the adopted cell partition for both algorithms. The inversion results can be represented in 2D images on different depth layers, or in pseudo-3D images.

Preliminary computation carried out separately on the two crustal seismic areas, MO3 and MO4, shows a similar thrust faulting regime ( $\mathbf{S}_{3}$ vertical) and roughly similar orientation of the principal horizontal stresses $\left(\mathbf{S}_{1}\right.$ and $\left.\mathbf{S}_{2}\right)$. However, taking into account the number of events and the relatively larger errors than for the subcrustal earthquakes, we considered a single area for the two crustal seismic areas, MO3 and MO4 together.

The results of stress inversion after application of StressInverse algorithm are presented in the Table 2 and in the Figures 4 and 5. Note several significant features coming up from table and graphical representations:

- in all cases (crust and slab layers) the $\mathbf{S}_{3}$ principal axis is close to vertical: axis plunge ranges from $71^{\circ}$ in the crust and $87^{\circ}$ in the bottom layers. This is compatible with a compressive stress regime. Correspondingly, the axes $\mathbf{S}_{1}$ and $\mathbf{S}_{2}$ are close to horizontal (plunge angles below $9^{\circ}$ in the slab and below $20^{\circ}$ in the crust);

- stress ratio (R) has values between $0.30 \pm 0.1$ to $0.84 \pm 0.09$ (VNI4 and VNI1). The confidence limits are spread because the shape ratio is sensitive to the number of focal mechanisms inverted and to their accuracy;

- there are two conjugate focal mechanisms (denoted as "principal focal mechanisms" by Vavrycuk) compatible with the stress configuration. For the subsequent discussions and graphic representations, we chose one of the conjugate focal mechanisms, the one with the parameters (strike/dip/rake) given in Table 2 and respectively two solutions of nodal planes. The fault plane solutions in Figures 4 and 5 correspond to the principal focal mechanism written in the table.
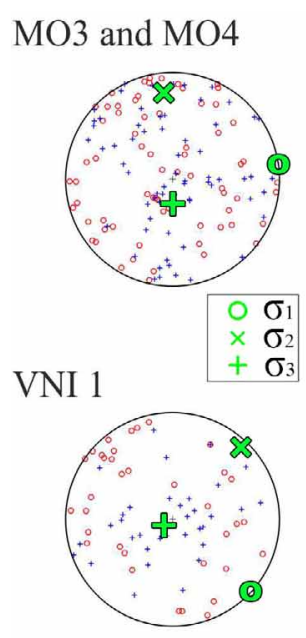

VNI 2

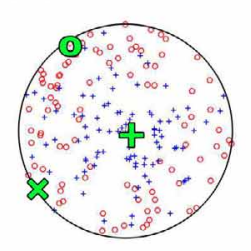

A
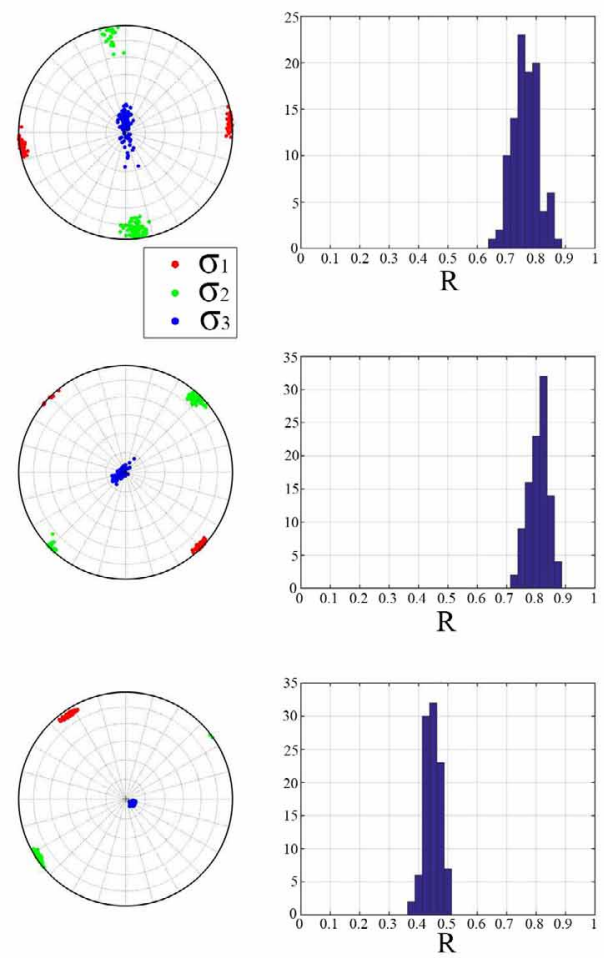

C
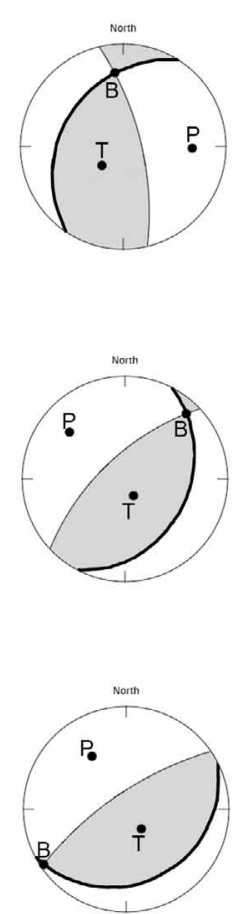

D

Figure 4. Principal diagrams obtained from StressInverse for the crustal zone MO3-MO4 and the first two intermediatedepth zones: VNI $1(55-80 \mathrm{~km})$ and VNI $2(81-105 \mathrm{~km})$. A) Lower hemisphere plots of P (red circles) and T axes (blue crosses); B) Scatter plot showing the confidence limits of the principal stress directions for 100 noisy calculations; C) Histogram of the shape ratio R for 100 noisy calculations. D) Fault plane solutions corresponding to the principal mechanism after the values of strike/dip/rake in the Table 2. 
Stress field pattern in the Vrancea zone

\begin{tabular}{|c|c|c|c|c|c|c|c|c|}
\hline Zone & $\begin{array}{c}\text { No. } \\
\text { Events }\end{array}$ & $\begin{array}{c}S_{1} \\
\text { Az./pl. }\end{array}$ & $\begin{array}{c}S_{2} \\
\text { Az./pl. }\end{array}$ & $\begin{array}{c}S_{3} \\
\text { Az./pl. }\end{array}$ & $\mathbf{R}$ & $\begin{array}{l}\text { Principal fault planes } \\
\text { computed per zone } \\
\text { (strike/dip/rake) }\end{array}$ & $\begin{array}{l}\text { Fault } \\
\text { type }\end{array}$ & $\begin{array}{c}\text { Stress } \\
\text { Regime }\end{array}$ \\
\hline \multicolumn{9}{|c|}{ Crustal seismic zone: 1 - $50 \mathrm{~km}$} \\
\hline MO3-MO4 & 74 & $84 / 1$ & $354 / 19$ & $177 / 71$ & $0.78 \pm 0.10$ & $213 / 28 / 133$ & $\begin{array}{l}\text { Thrust } \\
\text { faulting }\end{array}$ & $\begin{array}{l}\text { Compres- } \\
\text { sion }\end{array}$ \\
\hline \multicolumn{9}{|c|}{ Intermediate-depth seismic zone: 55 - $180 \mathrm{~km}$} \\
\hline VNI1 55-80 & 35 & $134 / 2$ & $43 / 8$ & $240 / 82$ & $0.84 \pm 0.09$ & $27 / 26 / 72$ & \multirow{7}{*}{ 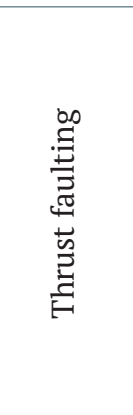 } & \multirow{7}{*}{ 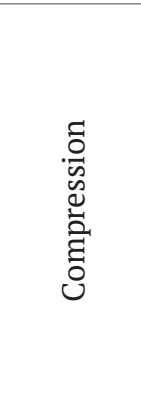 } \\
\hline VNI2 81-105 & 93 & $326 / 6$ & $236 / 2$ & $126 / 84$ & $0.46 \pm 0.12$ & $63 / 18 / 97$ & & \\
\hline VNI_A 55-105 & 128 & $322 / 4$ & $52 / 0$ & $142 / 86$ & $0.51 \pm 0.06$ & $52 / 19 / 90$ & & \\
\hline VNI3 106-130 & 172 & $318 / 6$ & $227 / 5$ & $97 / 82$ & $0.37 \pm 0.12$ & $59 / 22 / 103$ & & \\
\hline VNI4 131-155 & 285 & $125 / 3$ & $214 / 1$ & $322 / 87$ & $0.30 \pm 0.10$ & $37 / 33 / 98$ & & \\
\hline VNI5 155-180 & 49 & $148 / 1$ & $58 / 3$ & $264 / 87$ & $0.62 \pm 0.12$ & $52 / 24 / 83$ & & \\
\hline VNI_B 106-180 & 506 & $311 / 0$ & $222 / 2$ & $48 / 88$ & $0.29 \pm 0.10$ & $45 / 30 / 94$ & & \\
\hline
\end{tabular}

Table 2. Results obtained after inversion of mechanisms of subcrustal earthquakes (zones VNI1 - VNI5) and in crustal zone MO3-MO4 applying the code StressInverse. Abbreviations: Az.- azimuth; pl. - plunge.

The faulting type represented by a certain DC moment tensor can be determined by the orientation of its eigenvectors, $\mathrm{P}, \mathrm{B}$ and $\mathrm{T}$, in a sense which may apply to the characterization of the stress regime in an area. Zoback (1992) determined a set of rules for the classification of faulting type depending mainly on the plunge angles of the $\mathrm{P}$ and $\mathrm{T}$ axes, complemented, in some cases, by the respective plunge of the $\mathrm{B}$ axis (Table 3). These also determine the trend of the maximum horizontal stress axis, $S_{\mathrm{Hmax}}$.

There is a region of $\mathrm{P}$ and $\mathrm{T}$ plunges in which focal mechanisms are not classified in a typical faulting type, but rather as "odd" or "unknown" (U). This is the case of either sub-horizontal faults with horizontal slip or sub-vertical faults with (nearly vertical) dip-slip (both with plunge $\approx 45^{\circ}$ or all three axes with $25^{\circ}<p l<45^{\circ}$ ). Such cases are generally rare and may characterize very low-angle normal faults or thrusts where the principal stress field is tilted out of horizontal and vertical planes [Zoback, 1992; Heidbach et al., 2016a]. Our data presented in Table 2 support the conclusion that the results are all included in the line 6 of Table 3 and the tectonic regime is assigned to the category of thrust faulting. The conclusion is valid either for every layer considered in the subcrustal domain from VNI1 to VNI5, or for the principal subcrustal domains VNI_A (55 - $100 \mathrm{~km}$ depth) and VNI_B (101 - $180 \mathrm{~km}$ depth). Somewhat unexpectedly, the crustal part MO3-MO4, which is located above the subcrustal seismically active body, shows the same tectonic regime of thrust faulting.

\begin{tabular}{|c|c|c|c|c|}
\hline$P(\sigma 1)$ & $B(\sigma 2)$ & $\mathrm{T}(\sigma 3)$ & $\begin{array}{l}\text { Tectonic regime or } \\
\text { faulting type }\end{array}$ & $\mathrm{S}_{\mathrm{Hmax}}$ trend \\
\hline$p l_{\mathrm{P}} \geq 52^{\circ}$ & & $p l_{\mathrm{T}} \leq 35^{\circ}$ & & $a z_{\mathrm{N}}$ \\
\hline $40^{\circ} \leq \gamma_{\mathrm{P}}<52^{\circ}$ & & & NS & $a z_{\mathrm{T}}+90^{\circ}$ \\
\hline$p l_{\mathrm{P}}<40^{\circ}$ & $p l_{\mathrm{N}} \geq 45^{\circ}$ & $p l_{\mathrm{T}} \leq 20^{\circ}$ & SS & $a z_{\mathrm{T}}+90^{\circ}$ \\
\hline$p l_{\mathrm{P}} \leq 20^{\circ}$ & $p l_{\mathrm{N}} \geq 45^{\circ}$ & $p l_{\mathrm{T}}<40^{\circ}$ & SS & $a z_{\mathrm{p}}$ \\
\hline$p l_{\mathrm{P}} \leq 20^{\circ}$ & & $40^{\circ} \leq p l_{\mathrm{T}}<52^{\circ}$ & TS & $a z_{\mathrm{P}}$ \\
\hline$p l_{\mathrm{P}} \leq 35^{\circ}$ & & $p l_{\mathrm{T}} \geq 52^{\circ}$ & TF & $a z_{\mathrm{P}}$ \\
\hline $40 \leq p l_{\mathrm{P}} \leq 50^{\circ}$ & $p l_{\mathrm{N}} \approx 0^{\circ}$ & $40 \leq p l_{\mathrm{T}} \leq 50^{\circ}$ & U-"Odd" & - \\
\hline $25 \leq p l_{\mathrm{P}} \leq 45^{\circ}$ & $25 \leq p l_{N} \leq 45^{\circ}$ & $25 \leq p l_{\mathrm{T}} \leq 45^{\circ}$ & U-"Odd" & - \\
\hline
\end{tabular}

Table 3. Stress regime characterization based on the plunge, of $\mathbf{P}, \mathbf{B}$ and $\mathbf{T}$ axes (on the basis of them being an approximation of the principal stress axes S1, S2 and S3), where NF, SS and TF refer to normal, strike-slip and thrust faulting; NS and TS refer to oblique normal and thrust faulting. Symbols $\gamma$ and $\alpha$ refer to the plunge and trend, respectively of the principal axes [after Zoback, 1992; Kapetanidis and Kassaras, 2019]. 


\section{Andrei Bala et al.}

The seismicity pattern on depth (Figure 2), with a significant deficit at the transition from the crust to the subducted lithosphere, suggests a possible decoupling between the crustal and slab segments. However, the stress regime in the crust is of thrusting type even though it is less constrained than in the subducted lithosphere. For example, the range of the $\mathbf{S}_{3}$ axis plunge is larger $\left(71^{\circ}-86^{\circ}\right)$ in the overlying crustal domain (Figure 4: MO3-MO4) than in the subcrustal domain, where the plunge of $\mathbf{S}_{3}$ axis lies in a narrow domain of only $5^{\circ}\left(82^{\circ}-87^{\circ}\right)$ along the entire intermediate-depth domain $(55-180 \mathrm{~km})$, see Figure 5. Our results are thus rather in favor of a certain coupling between the stress regime in the subcrustal domain and that acting in the overlying crust.

The direction of the $\mathbf{S}_{1}$ axis is very similar (NW - SE) at all depth levels in the slab, perpendicular to the Carpathians Arc bend. The variation of the strike from one layer to the other ranges within $10^{\circ}-12^{\circ}$ (note that for an axis close to horizontal the strike $\alpha$ is equivalent with $\alpha \pm 180^{\circ}$ ). In the crust the $\mathbf{S}_{1}$ direction is rotated counterclockwise by about $45^{\circ}(\mathrm{E}-\mathrm{W})$ relative to the direction in the subcrustal domain. Equivalently, the $\mathbf{S}_{2}$ axis is oriented NE-SW in the slab and N-S in the crust.

If we compare the results obtained for the upper and lower segments (VNI_A - Figure 4 versus VNI_B - Figure 5), we note first the similarity in the configuration of the stress principal axes. Also, the orientation of the principal stress planes is close each other and follows the predominant orientation NE-SW of the Vrancea intermediatedepth seismicity. The only significant difference is the decrease of the stress ratio value in the deeper segment. As we shall discuss below, this variation correlates to a change in friction parameter and can be attributed to possible weakening processes activated below $100 \mathrm{~km}$ depth.

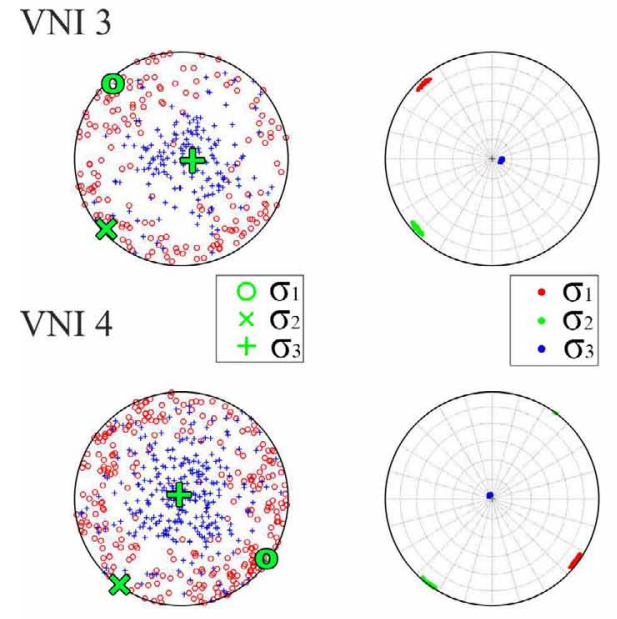

VNI 5

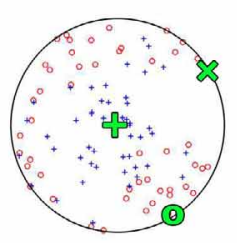

A

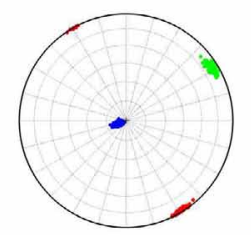

B
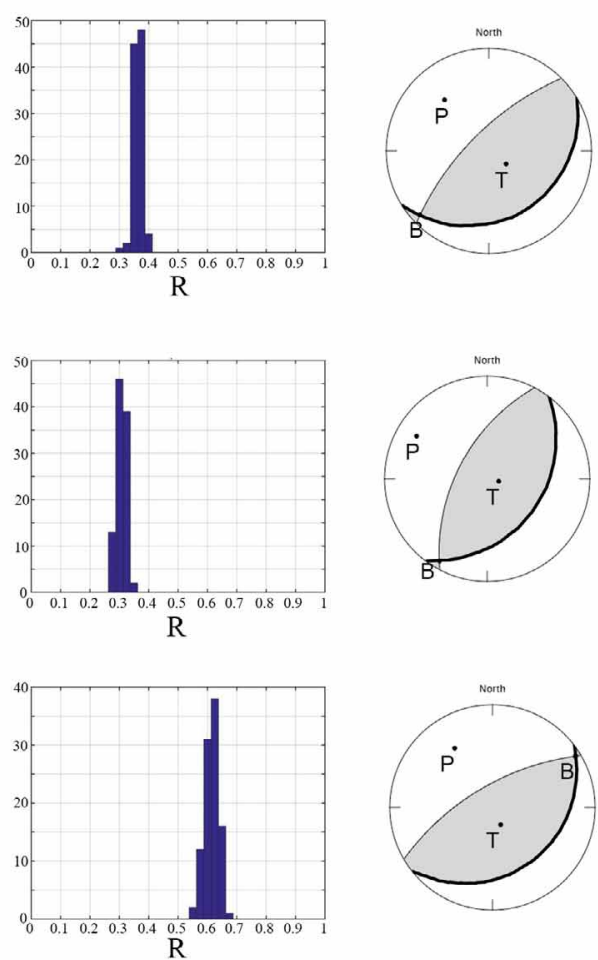

C

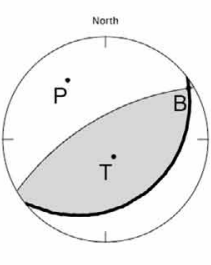

D

Figure 5. Principal diagrams obtained from StressInverse for the intermediate-depth zones VNI 3 (106 - $130 \mathrm{~km}$ ), VNI 4 (131- $155 \mathrm{~km}$ ) and VNI 5 (155 - $180 \mathrm{~km})$. A) Lower hemisphere plots of P (red circles) and T axes (blue crosses); B) Scatter plot showing the confidence limits of the principal stress directions for 100 noisy calculations; C) Histogram of the shape ratio R for 100 noisy calculations. D) Fault plane solutions corresponding to the principal mechanism after the values of strike/dip/rake in the Table 2. 


\subsection{Fault instability}

The fault plane instability, I, is an important parameter of evaluating the fault plane proposed by Vavryčuk et al. [2013] and Vavryčuk [2014]. Since differently oriented faults have a different susceptibility to be activated in a given stress field and thus one can define faults more or less unstable for this stress field, Vavryčuk et al. [2013] introduced a quantity to measure this instability defined by the following Equation:

$$
I=\frac{\tau-\mu(\sigma-\sigma 1)}{\tau c-\mu(\sigma-\sigma 1)}
$$

where $\tau_{\mathrm{c}}$ and $\sigma_{\mathrm{c}}$ are the shear traction and effective normal traction along the principal fault, and $\tau$ and $\sigma$ are the shear traction and effective normal traction along the analyzed fault; $\mu$ is the friction coefficient. Fault instability $I$ ranges from 0 (the most stable faults) to 1 (the most unstable faults). The most unstable fault is the optimally oriented fault for shear faulting called the principal fault.

It can be shown that the fault instability is independent of absolute stress values, and (2) can be expressed as a function of friction $\mu$, shape ratio $\mathrm{R}$ (Equation 1 ) and directional cosines $\mathrm{n}$ defining the inclination of the fault plane from the principal stress axes:

$$
I=\frac{\tau-\mu\left(\sigma-{ }_{1}\right)}{\mu+\sqrt{1+\mu^{2}}}
$$

where

$$
\begin{gathered}
\sigma=n_{1}^{2}+(1-2 R) n_{2}^{2}-n_{3}^{2} \\
\tau=\sqrt{n_{1}^{2}+(1-2 R)^{2} n_{2}^{2}+n_{3}^{2}-\left[n_{1}^{2}+(1-2 R) n_{2}^{2}-n_{3}^{2}\right]^{2}}
\end{gathered}
$$

The directional cosines $\boldsymbol{n}_{\mathbf{1}}, \boldsymbol{n}_{2}, \boldsymbol{n}_{3}$ define the inclination of the fault plane from the principal stress axes, $\boldsymbol{n}$ being expressed in the coordinate system of the principal stress directions [Vavryčuk, 2014].

To evaluate the fault instability using Equation (3), a value of friction $\mu$ is needed. Friction on faults most often ranges between 0.2 and 0.8 , but its value is usually unknown, especially at depth more than $50 \mathrm{~km}$. Numerical tests revealed, however, that the inversion is rather insensitive to $\mu$ [Vavryčuk, 2014], so it is often sufficient to assign some mean value to friction during the inversion, for example, $\mu=0.6$.

Another approach is to run the inversion for several values of friction and adopt the value which produces the highest overall instability of faults for the data inverted. This approach is used in the StressInverse algorithm in order to run synthetic tests as well as in the applications to real data [Vavryčuk, 2014].

Once StressInverse yields a friction coefficient $\mu$, which results in the highest overall instability, we compute fault instability $I$ using (3), (4) and (5). In order to compute the directional cosines $\left(\boldsymbol{n}_{\mathbf{1}}, \boldsymbol{n}_{2}, \boldsymbol{n}_{\mathbf{3}}\right)$, a useful algorithm is MohrPlotter, which is conveniently transforming all the parameters present in the Mohr circle (MohrPlotter v. 3.0 by Allmendinger, 2020).

An additional parameter that can be derived from the Mohr circle is the angle $\alpha$ :

$$
\alpha=45^{\circ}-\left(\tan ^{-1}(\mu)\right)
$$

which is the angle between the maximum shear stress and the fault slip measured in the plane defined by the normal to the fault and the slip direction.

The resulted parameters for the three principal domains: MO3-MO4 in the crust and VNI_A and VNI_B in the intermediate-depth domain of the Vrancea zone are summarized in Table 4. The first two parameters (R and $\mu)$ are results of the StressInverse program after inversion; $\alpha$ and I are obtained according to Equations (6) and (3). 
Seismic zone Stress ratio (R) Friction ( $\mu \quad \alpha=45^{\circ}-\left(\tan ^{-1}(\mu) / 2\right)$ Fault instability I

\begin{tabular}{cccccc} 
MO3-MO4 0-50 km & 0.78 & 1 & $22.5^{\circ}$ & 0.702 & $84^{\circ} / 354^{\circ}$ \\
\hline VNI_A 55-105 km & 0.51 & 0.95 & $23.2^{\circ}$ & 0.975 & $142^{\circ} / 52^{\circ}$ \\
\hline VNI_B 106-180 km & 0.29 & 0.55 & $30.6^{\circ}$ & 0.957 & $131^{\circ} / 42^{\circ}$ \\
\hline
\end{tabular}

Table 4. Parameters obtained after inversion with StressInverse program in the crust and in the two main levels defined in the slab.

To test how our results fit the regional stress map, we transformed the orientations of $\mathbf{S}_{1}$ and $\mathbf{S}_{3}$ to azimuths of maximum horizontal stress $\left(\sigma_{\mathrm{H}}\right)$ and minimum horizontal stress $\left(\sigma_{\mathrm{h}}\right)$, using the script of Lund and Townend [2007], which is also implemented in the MSATSI code of Martínez-Garzón et al. [2014]. The values obtained are given in Table 4 for crustal segment and the two principal segments in the slab and they are represented in Figure 10.

The decrease of stress ratio and static friction with depth is somewhat unexpected having in mind the inevitable increase in the normal stress. On the other side, the drop in friction from $\mu \sim 1$ in the first $105 \mathrm{~km}$ depth range (MO3 - MO4 and the upper Vrancea segment, VNI_A) to $\mu=0.55$ in the lower segment (VNI_B, below $105 \mathrm{~km}$ depth) correlates well with the increase in the earthquake generation (as frequency and size) in the bottom part of the Vrancea intermediate-depth source (VNI_B).

Laboratory measurements indicate for the sedimentary rocks in the upper part of the crust $\mu$ values between 0.6 and 1.0 [Byerlee, 1978; Townend and Zoback, 2000]. For deeper regions there are no direct measurements, but some authors consider that static friction might have values close to 1 at these specific depths, deeper than $50 \mathrm{~km}$ [Townend and Zoback, 2000]. We should keep in mind also that the values of static friction are significantly higher than the dynamic friction over the earthquake rupture area (friction at the seismic sliding rates of $\mathrm{m} / \mathrm{s}$ during the earthquake), $\mu<0.1$, due to various proposed weakening mechanisms [see Marone, 1998].

As shown in Figure 6, the principal stress axes for most domains are nearly horizontal and vertical. The method to distinguish the fault plane from the auxiliary plane is looking for the highest instability following the MohrCoulomb criterion.

Figure 6 represents the results of the stress inversion separated for all the 10 cells that we considered in VNI. For the first layer (VNI1) and last layer (VNI5) we merged all the events in a single cell, regardless their position. Therefore, the results are practically the same as in the Figures 4 and 5. The main result emphasizing a homogeneous stress field of thrust faulting and radial compression for all the layers is obtained also when considering individual cells.

A prevalent downdip extension regime in Vrancea subcrustal region was determined by Bala et al. (2019) from the statistical analysis of fault plane solutions (P, B, T axes), but it becomes more convincing through the stress inversion approach. The thrust faulting regime is extended towards crustal level in the area that overlies VNI MO3 and MO4 (Figure 7).

\subsection{Stress regime results obtained with MSATSI}

MSATSI [Martínez-Garzón et al. 2014] facilitates an automated procedure and MATLAB based visualization tools to represent the inversion results using a variety of plots. Figure 8 shows a 3D representation of the stress direction in VNI for the layers selected in inversion. The bootstrapping method proposed by Hardebeck and Michael [2006] is applied. A damping was applied in order to smooth the transition of the stress direction values from one cell to the other.

In all 10 cells from the vertical seismic zones VNI1 - VNI5 we have the same faulting type of thrust faulting determined in the Table 2 and plotted in Figure 4 and Figure 5, with $\mathbf{S}_{3}$ being very close to vertical and $\mathbf{S}_{1}$ and $\mathbf{S}_{2}$ which are having similar orientations, especially at the same level, for example at VNI3 and VNI4. 

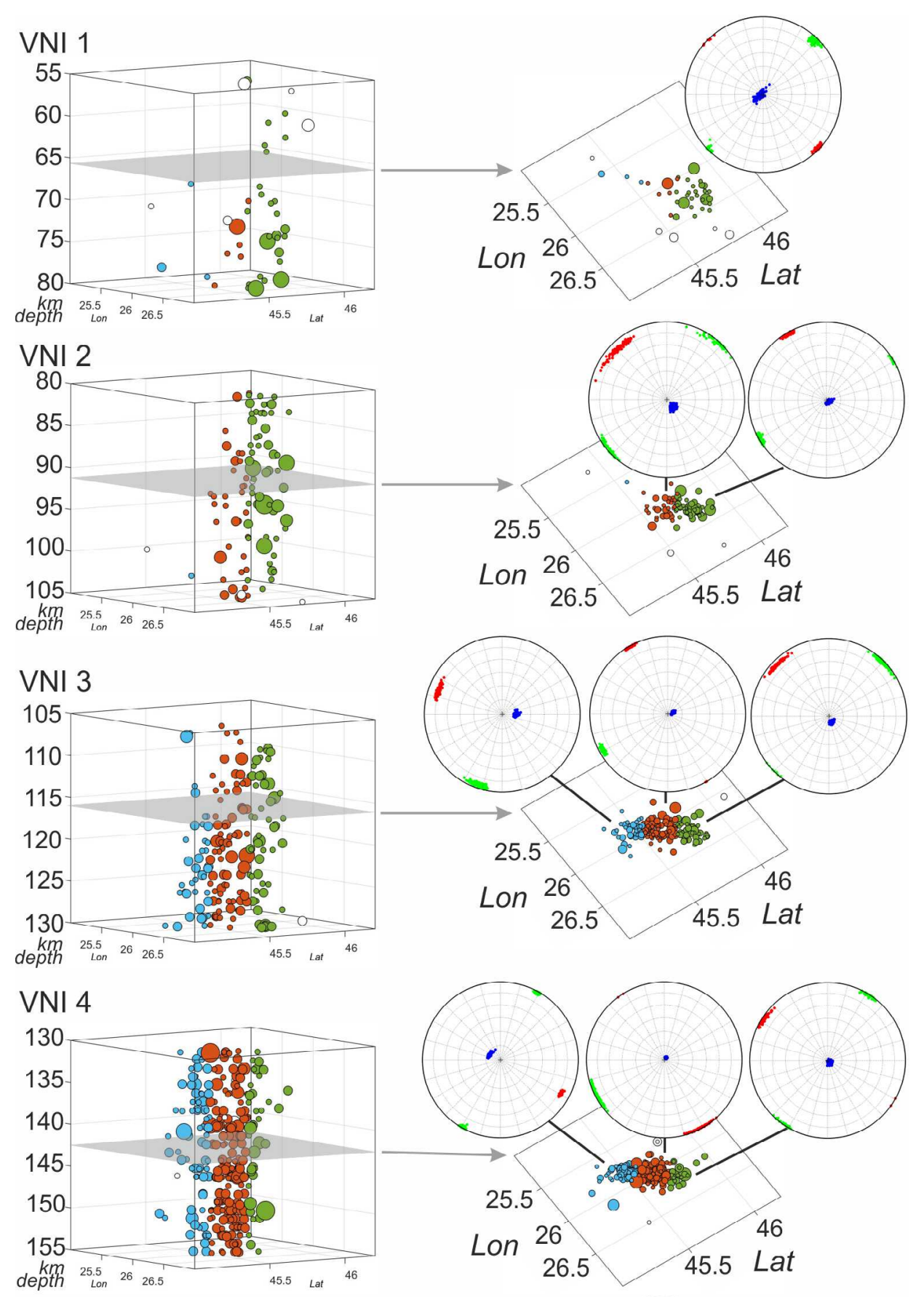

VNI 5

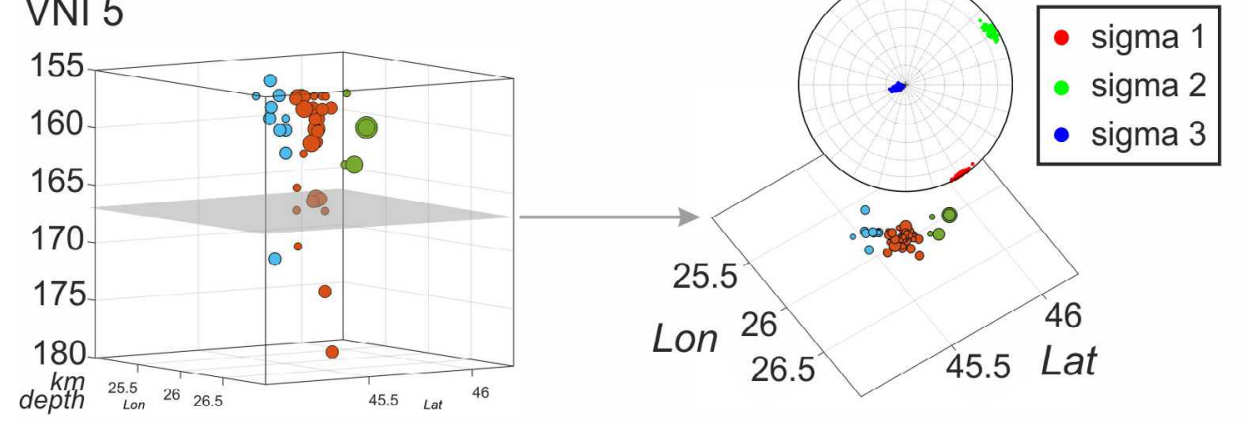

Figure 6. Seismicity and stress configuration in the intermediate-depth seismogenic volume on different layers and cells. Circles are colored depending on the relative position along slab (as in Figure 3): VNI NE (green), Middle (red) and VNI SW (blue). 


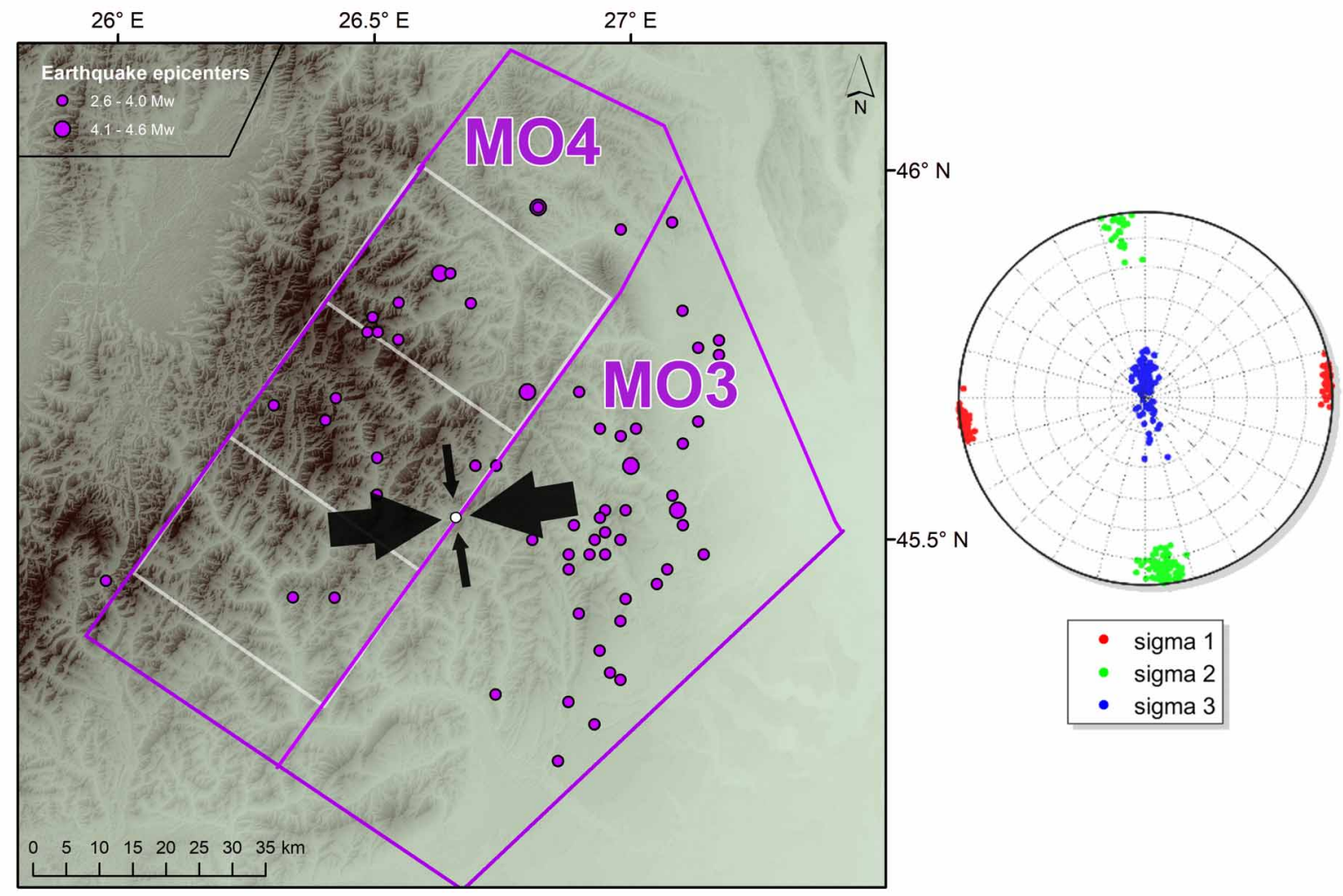

Figure 7. Earthquake epicenters in the seismogenic zones MO3 and MO4, overall faulting regime and a diagram of the stress axes (see Table 1).

From previous studies [Bala et al., 2019] we were aware that most of the earthquakes with mechanism in Vrancea slab are showing the same prevalent faulting type of thrust faulting mechanism (R - yellow or R-SS - orange in Figure 2). In the present study we have obtained thrust faulting and the corresponding tectonic mechanism of radial compression in all the 10 cells that we chose for inverting the event mechanisms in order to obtain the directions of the horizontal stress.

The conclusion is that at all subcrustal levels (VNI1 - VNI5) are in the presence of thrust faulting and compressive stress regime in which $\mathrm{S}_{\mathrm{H}}>\mathrm{S}_{\mathrm{h}}>\mathrm{S}_{\mathrm{v}}$. $\mathrm{S}_{\mathrm{Hmax}}$ and $\mathrm{S}_{\mathrm{hmin}}$ are showing similar directions at the same level from VNI1 to VNI5 with only minor changes in direction from one level to the other (Figure 6 and Figure 8).

This is an important evidence of the fact that the entire lithospheric block generating earthquakes beneath Vrancea region is subject of the same kind of forces resulted from a single stress field with homogeneous configuration.

\section{Discussion}

\subsection{Discussion of the results in correlation with principal boundaries in the crust and subducted slab}

The main goal of our study is to evaluate the stress field in the Vrancea and to investigate how this field correlates with the seismicity distribution at crustal and intermediate depths. The Vrancea seismic zone represents a concentrated nest of seismic activity with a considerable energy release at intermediate depth. There are specific patterns in the seismicity distribution in the study region which are described and discussed in different studies as landmarks of the seismotectonics of this area. 

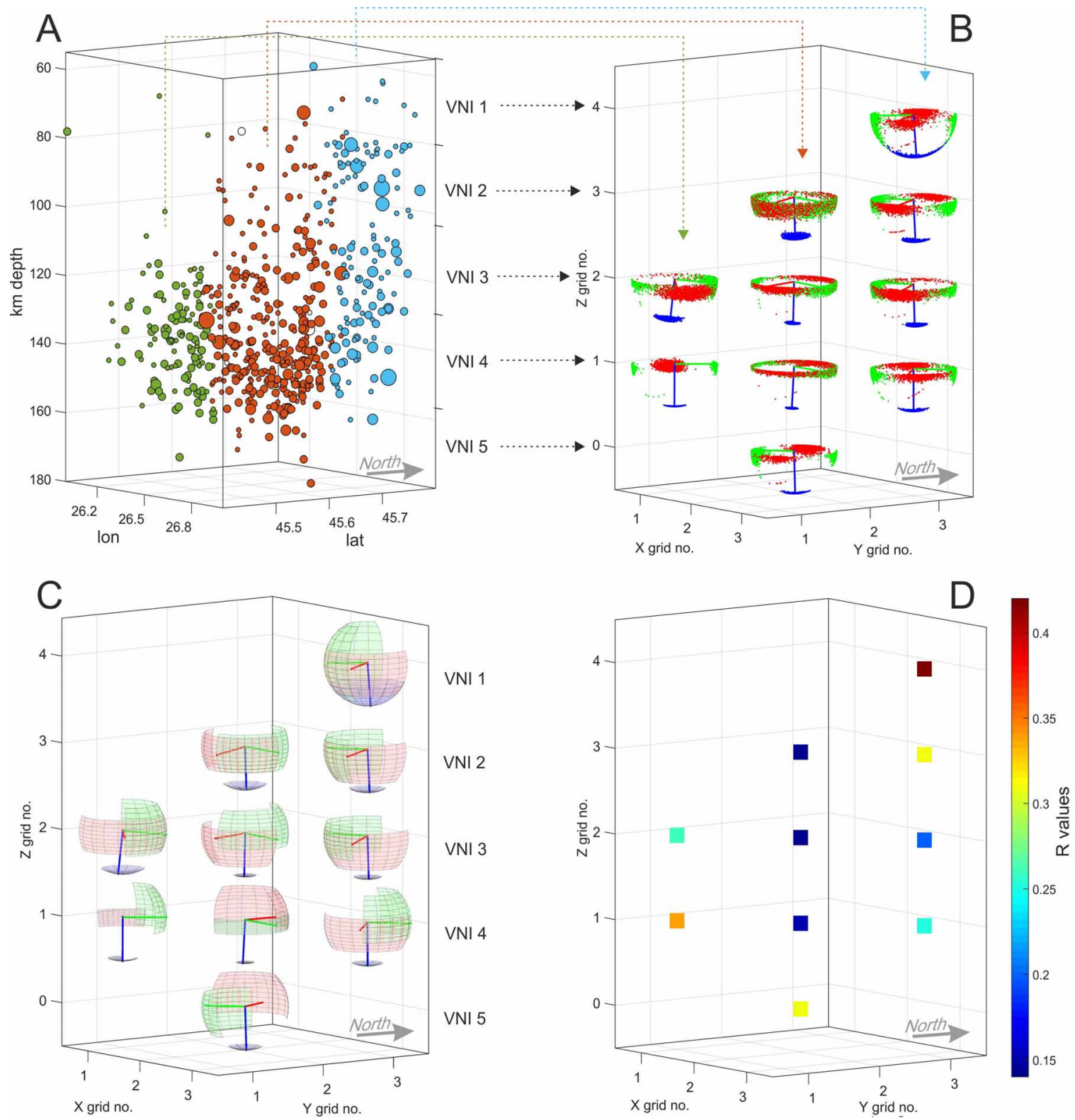

Figure 8. 3D Stress direction in Vrancea subcrustal zone computed with MSATSI package. A) 3D distribution of the earthquake with mechanism in VNI seismic zone; B) Stereomap plot showing the 3D distribution of stress axes in 10 cells in Vrancea zone; the 3D stereo plots are showing the $95 \%$ confidence regions of 2000 bootstrap resamples for the $S_{1}$ (blue), $S_{2}$ (green) and $S_{3}$ (red) axes; C) Stereomap plot showing stress uncertainties as bootstrap resampling (in dip angle, dip direction and rake). D) R values corresponding to the stress stereomap in C [after Martinez et al., 2014]. Number of cells and positions are given in Table 1.

First, the presence of a transitional layer between the crust and the seismic active body in the upper mantle is important to be analyzed. This layer placed roughly between 40 and $60 \mathrm{~km}$ depth seems to be unable to generate significant seismic activity. For this reason, it was considered as a seismic gap area [Fuchs et al., 1979; Hurukawa et al., 2005] and lead to the hypothesis of an oceanic slab detached from the crust and descending in the mantle beneath Vrancea [Fuchs et al., 1979; Oncescu, 1984]. However, Sperner et al. [2001] adjusted this hypothesis considering that the slab is not yet fully detached, because otherwise the high strain rates inside the slab (which indicate strong slab pull forces) are hard to be explained. The transition region was interpreted as a zone of weakened mantle or lower crustal material where slab detachment is presently taking place. 


\section{Andrei Bala et al.}

Tondi et al. [2009] considered this depth interval as a zone of partial melting which may result from delamination of the European mantle lithosphere and the upwelling of hot asthenospheric material. Also, the refraction seismic data suggest a low-velocity zone at a depth of 47 to $55 \mathrm{~km}$ beneath the Vrancea region [Hauser et al., 2007]. Although the depth to Moho boundary is established at $40-42 \mathrm{~km}$ in Vrancea area, with an abrupt increase in Vp from 7.0 to $7.9 \mathrm{~km} / \mathrm{s}$, there is another deeper layer, between 45 and $55 \mathrm{~km}$ depth, which marks a reversal of Vp velocity from 8.0 $\mathrm{km} / \mathrm{s}$ to $7.6 \mathrm{~km} / \mathrm{s}$. The structure under $55 \mathrm{~km}$ depth is characterized by a $\mathrm{Vp}=8.5 \mathrm{~km} / \mathrm{s}$ and is marking clearly the intrusion of a high-velocity slab in the lithosphere under the Moho. Given these data, we fixed the lower limit of the crustal domain to $50 \mathrm{~km}$ and the upper limit of the intermediate-depth seismic active body to $55 \mathrm{~km}$ depth.

The seismic activity in the bottom side of the seismogenic volume is sharply terminated at around $180 \mathrm{~km}$ depth, where probably a critical phenomenon inhibits the instability conditions able to generate brittle-like ruptures. According to the ROMPLUS earthquake catalogue [Oncescu et al., 1999; INFP, 2020], only four isolated earthquakes have been recorded so far below $180 \mathrm{~km}$, at depths between 186 and $218 \mathrm{~km}$ and with magnitudes between 3.2 and 4.1. It is worth mentioning that the seismogenic volume represents a relatively small part of a larger high-velocity body extended in depth to about $350 \mathrm{~km}$, with a rather complicated shaping [Martin et al., 2006].

The last seismicity feature we planned to investigate is the nature of the boundary at $100-110 \mathrm{~km}$ depth which makes transition from an upper active segment (VNI_A) to a lower active segment (VNI_B). According to some authors [Trifu and Radulian, 1994; Enescu and Enescu, 1998; Cărbunar and Radulian, 2011], the two segments are characterized by different seismicity patterns and triggering mechanisms and differences in the number of earthquakes and the energy released in both segments are established [Bala et al., 2001]. Notably, the seismic rate is approximately five times higher in the lower segment than in the upper segment, the average magnitude is systematically higher (by about 0.5 magnitude units) in the lower segment and the major shocks $\left(\mathrm{M}_{\mathrm{w}}>6.5\right)$ occur alternatively in the two segments. This boundary is also observed by Raykova and Panza [2006] in a study dedicated to the seismic properties of the lithosphere-asthenosphere system for the South-Eastern Carpathians from a large tomography project in the South-Eastern Europe. In the cell 16E of the model of Raykova and Panza [2006], which corresponds roughly with the Vrancea seismic zone, the shear wave velocity in the slab is established between 4.45 $-4.65 \mathrm{~km} / \mathrm{s}$ in the upper part of the slab down to $100 \mathrm{~km}$ depth and about $4.60-4.80$ in the lower part of the slab down to $170 \mathrm{~km}$ depth. Below that depth another interface is marking an important inversion in the seismic velocities to $4.30 \mathrm{~km} / \mathrm{s}$ with variations $4-4.55 \mathrm{~km} / \mathrm{s}$.

This boundary considered by seismological researches at $100-110 \mathrm{~km}$ depth might coincide with the lithosphere/asthenosphere boundary (LAB) as it was proposed by Enescu et al. [1992]. It coincides with the LAB position as considered for the regions surrounding the Vrancea region in more recent studies [Grinč et al., 2014]. The Moesian platform is well delineated by a relatively thick lithosphere, characterized by an E-W trend of lithospheric thickness decrease. In the east, near the Vrancea region, the thickness is about $110 \mathrm{~km}$ and in the west it is only 80 $\mathrm{km}$. In the same time the thickness of the lithosphere of the East European Platform is on average more than 120 $\mathrm{km}$, but in the northern part of this area some thicker places can be found Grinč et al. [2014].

\subsection{Discussion of the results in correlation in terms of field orientation and relative ratio $R$}

The main result of the present study is the homogeneity and consistency of the stress field regime along the entire Vrancea earthquake-prone body $\left(55-180 \mathrm{~km}\right.$ in depth). First, the $\mathbf{S}_{3}$ axis is close to vertical with a plunge angle of $84.40^{\circ} \pm 2.24^{\circ}$ (average of the plunge angles computed by inversion for the five subcrustal layers given in the Table 2). The reduced variability of axis orientation, which is obtained also when considering the results for individual cells instead of layers, is surprising taking into account the inherent errors in determining the fault plane solutions. We can firmly conclude that the stress field in the Vrancea subcrustal seismogenic zone is predominantly downdip extension along the vertically descending body. As a second important result, we note the invariance of the orientation of the principal horizontal axes, with $\mathbf{S}_{1}$ oriented perpendicularly and $\mathbf{S}_{2}$ tangentially to the Carpathians Arc bend: $138.20^{\circ} \pm 8.35^{\circ}$ (for $\mathbf{S}_{1}$ ) and $47.60^{\circ} \pm 8.78^{\circ}$ (for $\mathbf{S}_{2}$ ). The average values of $\sigma 1$ and $\sigma 2$ are computed using the values on the five layers in the Table 2, converted to the second and first quadrant, respectively. We note that this result remains the same when we use the values computed per 10 cells instead of 5 layers. It is the first time that such a coherent stress field regime is outlined for the Vrancea intermediate-depth source. The result has been anticipated to some extent in other studies as well [for example, Radulian et al., 1999], but either on the basis of 


\section{Stress field pattern in the Vrancea zone}

empirical inferences than computations, or based on a reduced number of earthquake mechanisms over a large area [Oncescu, 1987].

Oncescu [1987] performed stress inversion in the Vrancea region by applying the method of Gephart and Forsyth [1984] for 27 Vrancea intermediate-depth earthquakes recorded between 1934 and 1986. The results pointed out the vertical orientation of the $\sigma 3$ axis compatible with a predominant radial compression regime in the Vrancea. This is in agreement with the fault plane solutions showing preferred tension orientation ( $\mathrm{T}$ axes) consistent with the vertical or close to vertical extension in the slab [Bala et al., 2003]. Whereas the $\mathbf{S}_{3}$ axis orientation is consistent with the vertical tension stress pattern predicted by our study, the orientation of the horizontal axes, $\mathbf{S}_{1}$ oriented NE-SW and $\mathbf{S}_{2}$ oriented NW-SE, is practically rotated by $90^{\circ}$ as compared with our results and contradicts the most common modelling with principal compressive axis oriented NW-SE [e.g., Radulian et al., 2000; Sperner et al., 2001; Lorinczi and Houseman, 2009]. We can explain this discrepancy in the orientation of the horizontal stresses by the great change in data quality nowadays versus 1986 and also on the reduced number of mechanisms used in the inversion (27) which in the present work is considered as a lower limit.

Interestingly, Oncescu (1987) obtained a low value of stress ratio $(R=0.2)$ close to the $R$ value from our inversion in the lower Vrancea layer $(R=0.29)$. We note that from the total number of 27 events considered in Oncescu's analysis, 21 events are located in the lower Vrancea segment (VNI_B). In the same range, Protopopova and Botev [2019] determined for the Vrancea region a compressional stress regime, with $\mathrm{R}=0.3$.

In another study focused on a larger area centered on the Vrancea region, Müller et al. [2010] considered the maximum horizontal stress $\left(\sigma_{\mathrm{H}}\right)$ given by direct measurements in 94 boreholes with depths down to a maximum of $5.72 \mathrm{~km}$, which were spread around the Vrancea zone. After applying a smoothing algorithm over a grid radius of $40 \mathrm{~km}$ on a data set of 84 records, they come up with a mean value of the azimuth of $\mathbf{S}_{\mathrm{H}}=82.6^{\circ} \pm 55.7^{\circ}$, which is very close to our result of $84^{\circ}$, obtained by inversion applied to the focal mechanisms of 74 crustal events located in MO3-MO4, almost superimposed to the epicentral area of the Vrancea subcrustal earthquakes (Table 2 and Table 1).

As we know, the value of ratio $R$ expresses whether the value of $\sigma 2$ is closer to $\sigma 1$ or to $\sigma 3$. If we consider the Equation 1 and if we scale the reduced tensor as followed: $\sigma 1=1 ; \sigma 2=1-2 R ; \sigma 3=-1$. Then we have for VNI_A the values: $\sigma 1=1 ; \sigma 2 \sim 0 ; \sigma 3=-1$; and for VNI_B: $\sigma 1=1 ; \sigma 2=0.42 ; \sigma 3=-1$, which means that the magnitudes of the principal stresses are not close to each other as it was proposed by Muller et al. [2010] for the crustal part. The difference in $\mathrm{R}$ value between VNI_A and VNI_B involves some variation of the tectonic regime among the two segments. In VNI_A we have $\sigma 2$ which is placed in the middle of the domain established by $\sigma 1$ and $\sigma 3$. While in VNI_B the $\sigma 2$ is closer to $\sigma 1$ and the tectonic regime is much more homogeneous due to close values of the two horizontal stresses. We conclude that the variation in seismic behavior between the two segments might be due to the difference in tectonic regimes surrounding the slab, not only due to the composition in the slab itself.

\subsection{Models of the tectonic stress in the slab}

The numerical modelling developed by Ismail-Zadeh et al., [2005a; 2005b] begin to model the descending slab in the Vrancea zone based on the first model in the area obtained by Martin et al. [2001].

The modelling continued in the next stage [Ismail-Zadeh et al., 2007, 2008] starting from the 3D tomographic image obtained by Martin et al. [2006] for the high-velocity slab descending in the mantle. The upper-mantle seismic velocity anomalies are usually associated with significant temperature variations, so that the presence of a highvelocity body down to about $350 \mathrm{~km}$ depth (as coming out from seismic tomography experiment) implies lower temperature in the slab down to this depth relative to the neighboring asthenosphere. To evaluate temperature, Ismail-Zadeh et al. [2005b, 2008] inverted the P-wave anomalies into temperature taking into account the effects of mantle composition, anelasticity and partial melting. The contrast of temperature between the cold high-velocity slab and the warm asthenosphere generates stress acting in the slab region. The numerical computations led to a 3D stress field with the maximum principal stress oriented horizontally and minimum principal stress oriented vertically, and with the highest stress values distributed in the seismically active part of the descending place, localized at depths of about 70-170 km. Therefore, the enhancement in the computed stress field coincides with the seismogenic volume beneath Vrancea, and the stress configuration is consistent with the stress determination based on the focal mechanisms as obtained in the present study. 


\section{Andrei Bala et al.}

The maximum shear stress determined by Ismail-Zadeh et al. [2007] under South-East Carpathians at the intermediate depths stress is gradually changing from $80-90 \mathrm{MPa}$ at $70 \mathrm{~km}$ depth, to $70-80 \mathrm{MPa}$ at $100 \mathrm{~km}$ and 70 $75 \mathrm{MPa}$ at $130 \mathrm{~km}$ depth, 50-60 MPa at $160 \mathrm{~km}$ and around $50 \mathrm{MPa}$ at $190 \mathrm{~km}$ depth. According to this modelling the stress is greater in the upper segment of the seismogenic volume $(55-105 \mathrm{~km})$ than in the lower one $(106-180 \mathrm{~km})$, whereas the release of the seismic energy is greater in VNI_B than in VNI_A. To overcome this discrepancy, we assume that the elastic properties of the material in the lower segment VNI_B change significantly as a result of increasing pressure and temperature, some authors suggesting also that faulting due to metamorphic phase transitions [Green and Burnley, 1989] or dehydration-induced embrittlement [Hacker et al., 2003] may also play a role in the regional stress generation and release. This variation in the rheology of the slab is to some extend supported by the variation of stress ratio $\mathrm{R}$ and friction coefficient $\mu$ parameters as resulted from the stress inversion.

\subsection{Stress regime modelling at the South-Eastern Carpathians Arc bend}

In the Figure 9 we draw a schematic representation of the stress field regime in the study area following the results obtained by the inversion procedure applied in this paper. The first key element of the model is the predominant downdip extension regime with almost vertical elongation $\left(\mathbf{S}_{3}\right)$ and horizontal compression along the entire segment of the lithospheric slab which is seismically active (55 to $180 \mathrm{~km}$ in depth). The second key element is the orientation of the maximum compressive axis $\left(\mathbf{S}_{1}\right)$ and of the intermediate compressive axis $\left(\mathbf{S}_{2}\right)$ perpendicular to and respectively parallel to the Carpathians Arc bend. This configuration is present at any depth level with some slight variation in the orientation of the axes.

As regards the stress regime in the crustal area situated above Vrancea subcrustal source, we obtained thrust regime similar with the stress in the slab. A significant variation is observed in the orientation of the horizontal compressive axes $\left(\mathbf{S}_{1}\right.$ and $\mathbf{S}_{2}$ ) which are rotated by about $90^{\circ}$ relative to the configuration in the slab.

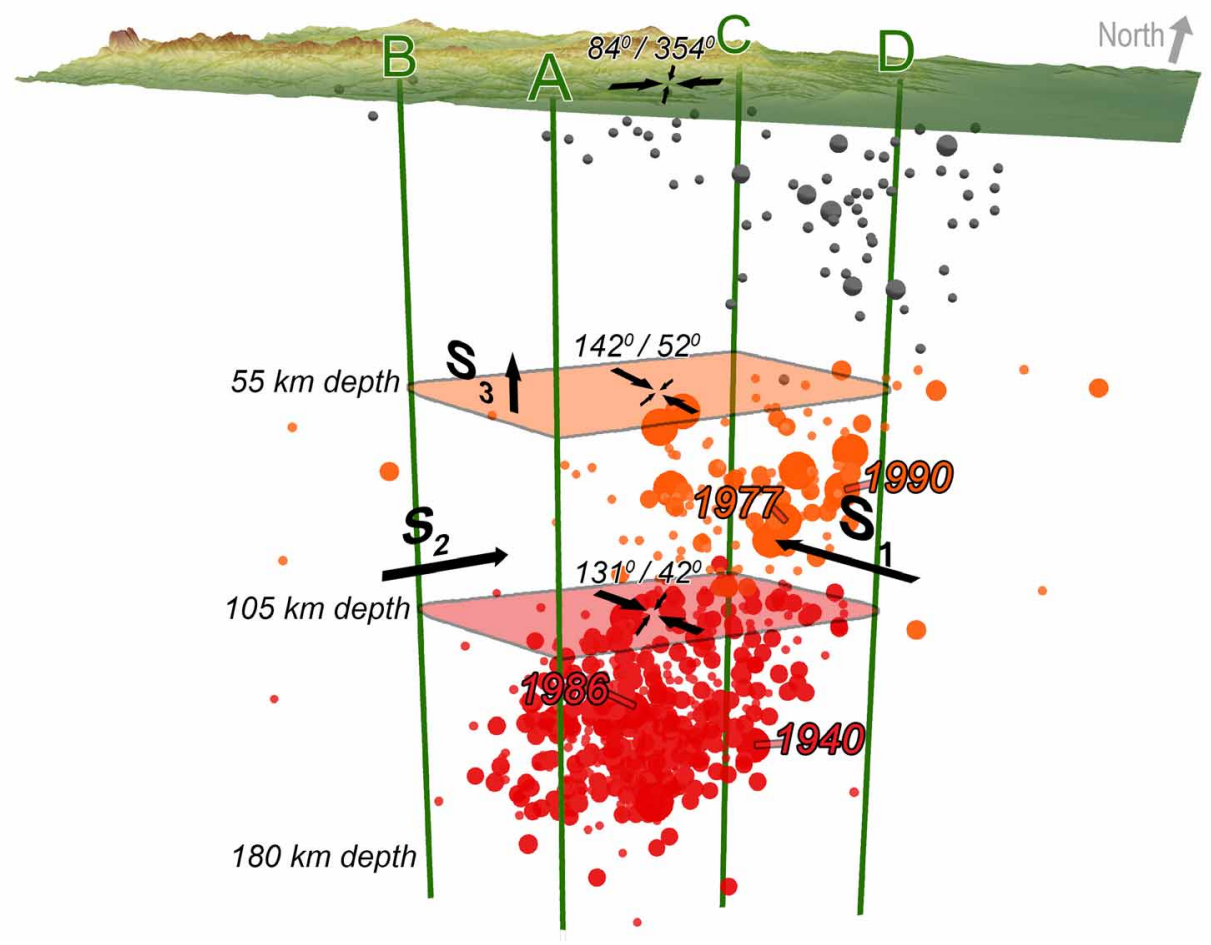

Figure 9. 3D model of the Vrancea region, showing main stress axes for the MO3 - MO4, VNI_A and VNI-B levels (smaller arrows), as well as the location of major earthquakes with $\mathrm{Mw} \geq 6.9$ with focal mechanisms represented in Figure 10. The larger arrows for $S_{1}, S_{2}$ and $S_{3}$ (Table 4) are representative for the seismogenic volume in the entire slab. 
This compressive regime is localized close to the Vrancea epicentral area (MO2-MO3 in our analysis) and turns into an extensional regime as we go away from this area.

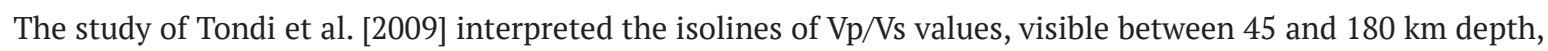
in relation with the downgoing slab geometry. Thus, they interpreted where the limit of $\mathrm{Vp} / \mathrm{Vs}=1.65$ which occur at $180 \mathrm{~km}$ depth as the possible transition from continental to oceanic crust in the slab itself. The model shows a steep zone delimited by the 1.70 isoline which might be the boundary which we considered at $110 \mathrm{~km}$ depth. Although such a steep boundary could be suggested in our 3D representation of Figure 2, it is hard to be delimited, since it has probably a thickness of a few kilometers only. According to Radulian [2014], the region around $110 \mathrm{~km}$ depth might be a region in which mantle material has penetrated and the conditions for occurrence of earthquakes are considerably reduced. The considered region of depth might be a transition zone between two earthquake-prone segments, VNI_A (upper segment) located approximatively between 55 and $105 \mathrm{~km}$ depth and VNI_B (lower segment), located approximatively between 106 and $180 \mathrm{~km}$ depth, as considered in our paper (Table 2). Although the seismicity rate and magnitude (energy release) differ in the two segments by a factor of $\sim 5$ and $\sim \Delta \mathrm{M} 0.5$ respectively, the orientation of the stress principal axes looks like to be practically the same all along the seismic active volume (within $\pm 5^{\circ}$ which is at the level of errors). Instead, the value of the computed stress ratio (R) is decreasing from the crust (0.78 in the MO3-MO4) to the VNI_A segment (0.51) and the VNI_B segment (0.29). Also, the friction coefficient $(\mu)$ is decreasing and instability coefficient (I) is increasing with depth getting higher. Note the strong decrease in the friction coefficient from the upper (VNI_A) and lower (VNI_B) intermediate-depth segments: 0.95 to 0.55 . They draw the attention to possible changes in the internal processes generating earthquakes that might differ in the two depth zones VNI_A and VNI_B. The high instability coefficient which is similar in the two segments should be related to the high capability of them to generate large earthquakes.

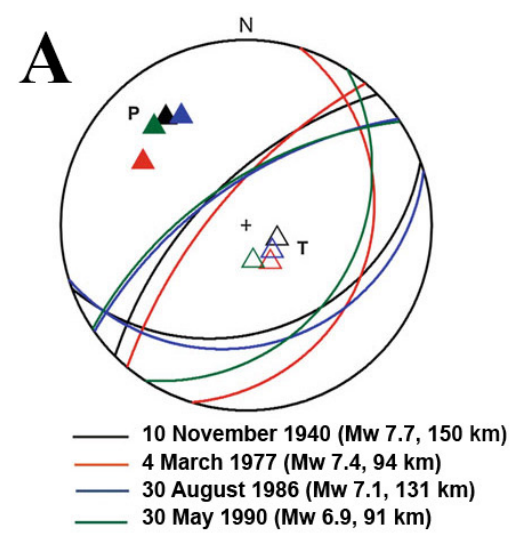

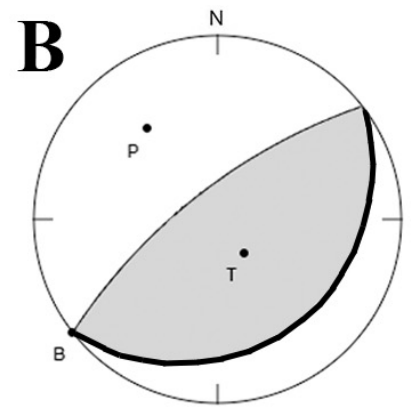

VNI A (55 - $105 \mathrm{~km})$

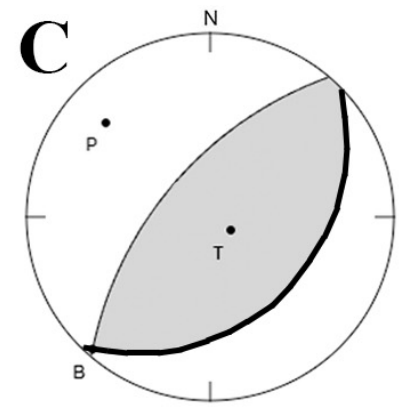

VNI B (106 - $180 \mathrm{~km})$

Figure 10. Principal mechanisms in Vrancea zone. A) Four earthquakes with $\mathrm{Mw} \geq 6.9$ in the catalogue (after Radulian, 2014). B) and C) Principal mechanisms (strike, dip of two principal focal mechanisms found for the retrieved optimum stress tensor in Table 2) for the VNI A and VNI B segments.

\section{Conclusions}

In the present study we computed the stress field pattern in the Vrancea area by inverting the earthquake focal mechanisms using an extended and complete set of fault-plane solutions available for the Vrancea intermediatedepth and crustal earthquakes recorded between 1929 and 2012 [Radulian et al., 2018, 2019].

The earthquake mechanisms for the Vrancea intermediate-depth earthquakes reveal predominant vertical tension and horizontal compression with variable directions [Heidbach et al., 2007]. However, the fault planes tend to align along NE-SW, following the elongated distribution in the same direction of seismicity, in accordance a NWSE compression, perpendicular to the Carpathians Arc [Oncescu and Trifu, 1987; Radulian et al., 1999]. 


\section{Andrei Bala et al.}

The data allowed us to perform the investigation on 3D gridding by splitting the seismogenic volume in six layers and 12 cells containing minimum 30 events each. This number threshold is considered adequate for statistical analysis to determine mean horizontal stress directions and stress regimes. For the subcrustal domain $(55-180 \mathrm{~km})$ in all cases (5 layers and 10 cells) the stress pattern shows similar orientation of the stress axes: $\mathbf{S}_{3}-$ vertical, $\mathbf{S}_{1}-$ NE-SW oriented, $\mathbf{S}_{2}-\mathrm{NW}$-SE oriented. Our result assumes a unitary stress behavior of the entire seismic active block descending in the mantle.

The same characteristics are obtained in the overriding crust, but slightly less constrained. Note that this behavior of the tectonic regime is observed in the crust just above and adjacent to the Vrancea slab projection. As shown in Bala et al. [2020], the stress regime changes significantly if we move away from the Vrancea area. Keeping the stress regime in the crustal domain above the sinking slab proves that the stress is transmitted along the slab to the surface and that the seismicity in the overriding crust should be somehow influenced by the seismicity in the slab. Therefore, our results are in favor of a model with certain coupling between the stress regime in the subcrustal domain and that acting in the overlying crust against a model of total break-off.

The regional stress field computed in the last version of the World Stress Map [Heidbach et al., 2016a, 2016b] indicates for the SE Romania a strong prevalent sub-horizontal orientation of $\mathrm{SH}_{\max }$ at crustal level which is close to our results for the MO3-MO4 seismic region: the maximum horizontal stress field oriented E-W to ENE-WSW (see Figure 7).

It is interesting to note that the similarity observed for the fault plane solutions of the major Vrancea earthquakes [e.g., Radulian, 2014] fits the principal mechanisms as they come out from the present inversion approach (Figure 10). In this figure we selected the fault plane solution associated to the principal fault plane resulted from inversion with the nodal plane dipping toward NW closer to vertical. As shown by previous investigations on the focal mechanism for the Vrancea major events, the real fault plane is the one dipping toward NW (dip of $60^{\circ}-70^{\circ}$ ). This is a strong argument to consider that the stress field regime acting upon the entire slab volume generating intermediate-depth earthquakes in Vrancea is compatible with a predominant faulting plane oriented NE-SW and inclined toward NW, plane which defines at the same time the seismicity pattern. In other words, the stress regime inferred by us from inversion of focal mechanisms is controlling the earthquake generation in the Vrancea intermediate depth domain both at small scale (small and moderate magnitude) and at major earthquake scale.

Data and sharing resources. The Romanian Earthquake Focal Mechanism Catalogue (REFMC 1929 - 2012) is the basis for analysis. It can be downloaded and used according to its license using the Mendeley Data repository https://data.mendeley.com/datasets/mykkx4gygy [Radulian et al., 2020]. For stress inversion we used StressInverse [Vavryčuk, 2014] and MSATSI [Martinez-Garzon et al., 2014] software. For the computation of the directional cosines and fault instability (I) in Table 4 we used MohrPlotter v. 3.0 [Allmendinger, 2020]. Figures 1, 2, 3, 7 and 9 were plotted mostly using the ESRI ArcMap and ArcScene software. For the other figures we used Matlab along with Adobe Photoshop. For focal mechanisms we used the WOLFRAM Demonstration Project "Earthquake focal mechanism" of Scherbaum F., Kuehn N. and Zimmermann B. [2009]. Open content licensed under CC BY-NC-SA. All the computer packages are used only for scientific work which resulted in the present paper.

Acknowledgements. We would like to thank Vàclav Vavryčuk, the principal author of the software package StressInverse, who permitted the public use for scientific purposes of the software package and described the use of it in several papers. We are also in debt to the creators of software package MSATSI, led by Patricia Martínez-Garzón, who also permitted the public use of the software and described it in several cited papers. This work was partially financed by the Pre-Quake project (number PN-III-P1-1.1-PD-2019-0969) supported by a grant of the Romanian Ministry of Research, Innovation and Digitalization, CNCS/CCCDI - UEFISCDI, within PNCDI III. Nevertheless, we thanks to the two anonymous reviewers whose critical recommendations let to a significant improvement of the paper quality.

\section{References}

Allmendinger, R.W. (2020). MohrPlotter v. 3.0, available from https://www.rickallmendinger.net/mohrplotter, last accessed: 20 December 2020. 
Álvarez-Gómez, J.A. (2019). FMC-Earthquake focal mechanisms data management, cluster and classification, SoftwareX, 9, 299-307, doi:10.1016/j.softx.2019.03.008.

Álvarez-Gómez, J.A. (2014). FMC: a one-liner Python program to manage, classify and plot focal mechanisms, Geophys. Res. Abstr. 16, EGU2014-10887.

Angelier, J. (2002). Inversion of earthquake focal mechanisms to obtain the seismotectonic stress IV - a new method free of choice among nodal planes, Geophys. J. Int., 150, 588-609.

Bada, G., F. Horváth, P. Dövényi, P. Szafián, G. Windhoffer and S. Cloetingh (2007). Present-day stress field and tectonic inversion in the Pannonian basin, Glob. Planet. Change, 58, 165-180.

Bala, A., M. Diaconescu and M. Biter (2001). Spatial distribution of the earthquakes in the Vrancea zone and tectonic correlations, Romanian J. Phys., 46, 459-474.

Bala, A., M. Radulian and E. Popescu E. (2003). Earthquakes distribution and their focal mechanism in correlation with the active tectonic zones of Romania, J. Geodyn., 36, 129-145.

Bala, A., D. Toma-Danila and M. Radulian (2019). Focal mechanisms in Romania: statistical features representative for earthquake-prone areas and spatial correlations with tectonic provinces, Acta Geodaetica et Geophysica, 54, 263-286.

Bala, A., M. Radulian and D. Toma-Danila (2020). Crustal stress partitioning in the complex seismic active areas of Romania, Acta Geodaetica et Geohysica, 55, 389-403, doi: 10.1007/s40328-020-00299-0.

Bocin A., R. Stephenson, L. Matenco and V. Mocanu (2013) Gravity and magnetic modelling in the Vrancea Zone, south-eastern Carpathians: Redefinition of the edge of the East European Craton beneath the south-eastern Carpathians, J. Geodyn., 71, 52-64

Bott, M.H.P. (1959). The mechanics of oblique- slip faulting, Geol. Mag., 96, 109- 117.

Byerlee, J. D. (1978). Friction of rocks, Pure Applied Geophys., 116, 615-629.

Cărbunar, O.F. and M. Radulian (2011). Geometrical constraints for the configuration of the Vrancea (Romania) intermediate-depth seismicity nest, J. Seismol., 15, 579-598.

Enescu, D. (1980). Contributions to the knowledge of the focal mechanism of the Vrancea strong earthquakes of March 4, 1977, Rev. Roum. Géol. Géophys. Géogr. Ser. Géophys., 24, 1, 3-18.

Enescu, D. and B.D. Enescu (1998). Seismotectonic model regarding the genesis and the occurrence of the Vrancea (Romania) earthquakes, Rom. Rep. Phys., 50, 97-122.

Enescu, D., D. Danchiv and A. Bala (1992). Lithosphere structure in Romania. II. Thickness of the Earth crust. Depthdependent propagation velocity curves for the $\mathrm{P}$ and $\mathrm{S}$ waves, Studii si cercetari de Geofiz., 30, 3-19.

Fojtíková, L. and V. Vavryčuk (2018). Tectonic stress regime in the 2003-2004 and 2012-2015 earthquake swarms in the Ubaye Valley, French Alps, Pure Appl. Geophys., 175, 1997 - 2008.

Fuchs, K., K.P. Bonjer, G. Bock, I. Cornea, C. Radu, D. Enescu, D. Jianu, A. Nourescu, G. Merkler, T. Moldoveanu and G. Tudorache (1979). The Romanian earthquake of March 4, 1977; II, Aftershocks and migration of seismic activity, Tectonophysics, 53, 225-247.

Ganas, A., B. Grecu, E. Batsi and M. Radulian (2010). Vrancea slab earthquakes triggered by static stress transfer, Nat. Hazards Earth Syst. Sci., 10, 2565-2577.

Gephart, J.W. (1990). FMSI: A FORTRAN program for inverting fault/slickenside and earthquake focal mechanism data to obtain the regional stress tensor, Comput. Geosci., 16, 953-989.

Gephart, J.W. and D.W. Forsyth (1984). An improved method for determining the regional stress tensor using earthquake focal mechanism data: application to the San Fernando earthquake sequence, J. Geophys. Res., 89, 9305-9320.

Gorgun E., K. Kekovali and D. Kalafat (2016). The 16 April 2015 Mw 60 offshore eastern Crete earthquake and its aftershock sequence implications for local regional seismotectonics, Int. J. Earth Sci., 106, 1735-1751.

Green H.W. and P.C. Burnley (1989). A new self-organizing mechanism for deep-focus earthquakes, Nature, 341, $733-737$.

Griggs, D.T. and D.W. Baker (1969). The origin of deep focus earthquakes, in Properties of Matter under Unusual Conditions (Eds. H. Mark and S. Fernback), Wiley Interscience, New York.

Grinč, M., H. Zeyen and M. Bielik (2014). Automatic 1D integrated geophysical modelling of lithospheric discontinuities: a case study from Carpathian-Pannonian Basin region, Contrib. Geophys. Geod., 44/2, 115-131.

Hacker, B.R., G.A. Abers and S. M. Peacock (2003). Subduction factory, 1, Theoretical mineralogy, densities, seismic wave speeds, and H2O contents, J. Geophys. Res., 108, B1, doi:10.1029/2001JB001127. 


\section{Andrei Bala et al.}

Hardebeck, J.L. and A.J. Michael (2006). Damped regional-scale stress inversions: Methodology and examples for southern California and the Coalinga aftershock sequence, J. Geophys. Res., Solid Earth, 111, B11310, doi 10.1029/2005JB004144.

Hauser, F., V. Raileanu, W. Fielitz, C. Dinu, M. Landes, A. Bala and C. Prodehl (2007). Seismic crustal structure between the Transylvanian Basin and the Black Sea, Romania, Tectonophysics, 430, 1-25.

Heidbach, O., J. Reinecker, M. Tingay, B. Muller, B. Sperner, K. Fuchs and F. Wenzel (2007). Plate boundary forces are not enough: Second- and third-order stress patterns highlighted in the World Stress Map database, Tectonics, 26, TC6014, doi:10.1029/2007TC002133.

Heidbach, O., A. Barth, B. Muller, J. Reinecker, O. Stephansson, M. Tingay and A. Zang (2016a). WSM Technical Report 16-01, available at http://www.world-stress-map.org/fileadmin/wsm/pdfs/WSM_TR_16-01.pdf.

Heidbach, O., S. Custodio, A. Kingdon, M.T. Mariucci, P. Montone, B. Müller, S. Pierdominici, M. Rajabi, J. Reinecker, K. Reiter, M. Tingay, J. Williams and M. Ziegler (2016b). Stress Map of the Mediterranean and Central Europe, GFZ Data Services, http://doi.org/10.5880/WSM.Europe2016.

Hurukawa, N., M. Popa and M. Radulian (2005). Vrancea intermediate-depth earthquakes in Romania-seismicity and mechanisms, J. Balkan Geophys. Soc., 8, S.1, 310 - 313.

INFP (National Institute for Earth Physics, Romania) (2020). ROMPLUS earthquake catalogue, available at www.infp.ro

Ismail-Zadeh, A., B. Mueller and G. Schubert (2005a). Three-dimensional modeling of present day tectonic stress beneath the earthquake-prone southeastern Carpathians based on integrated analysis of seismic, heat flow, and gravity observations, Phys. Earth Planet. Int., 149, 81 - 98.

Ismail-Zadeh, A., B. Mueller and F. Wenzel (2005b). Modelling of descending slab evolution beneath the SECarpathians: implications for seismicity, in Persp. Mod. Seismo., 203-223.

Ismail-Zadeh, A., V. Sokolov and K.P. Bonjer (2007). Tectonic stress, seismicity, and seismic hazard in the southeastern Carpathians, Nat. Hazards, 42, 493-514.

Ismail-Zadeh, A., G. Schubert, I. Tsepelev and A. Korotkii (2008). Thermal evolution and geometry of the descending lithosphere beneath the SE-Carpathians: An insight from the past, Earth Planet. Sci. Lett., 273, 68-79.

Ismail-Zadeh, A., L. Maţenco, M. Radulian, S. Cloetingh and G.F. Panza (2012). Geodynamics and intermediatedepth seismicity in Vrancea (The South-Eastern Carpathians): Current state-of-the art, Tectonophyiscs, 530-531, 50-79.

Kapetanidis, V., and I. Kassaras (2019). Contemporary crustal stress of the Greek region deduced from earthquake focal mechanisms, J. Geodyn., 123, 55-82.

Kaverina, A.N., A.V. Lander and A.G. Prozorov (1996). Global creepex distribution and its relation to earthquakesource geometry and tectonic origin, Geophys. J. Int., 125, 1, 249-265.

Koulakov, I., B. Zaharia, B. Enescu, M. Radulian, M. Popa, S. Parolai and J. Zschau (2010). Delamination or slab detachment beneath Vrancea? New arguments from local earthquake tomography, Geochem. Geophys. Geosyst. (G3), 11, 3, Q03002, doi:10.1029/2009GC002811.

Lorinczi, P. and G. Houseman (2009). Lithospheric gravitational instability beneath the South East Carpathians, Tectonophysics, 474, 1-2, 322-336.

Lund, B. and R. Slunga (1999). Stress tensor inversion using detailed microearthquake information and stability constraints: Application to Olfus in southwest Iceland, J. Geophys. Res., 104, 14947-14964.

Lund, B. and J. Townend (2007). Calculating horizontal stress orientations with full or partial knowledge of the tectonic stress tensor, Geophys. J. Int., 170, 1328-1335.

Kapetanidis, V. and I., Kassaras (2019). Contemporary crustal stress of the Greek region deduced from earthquake focal mechanisms, J. Geodyn., 123, 55-82.

Marone, C. (1998). Laboratory-derived friction laws and their application to seismic faulting, Ann. Rev. Earth Planet. Sci., 26, 643 - 696.

Martin, M, U. Achauer, E. Kissling, V. Mocanu, G. Musacchio, M. Radulian, F. Wenzel and CALIXTO Working Group (2001). First results from the tomographic experiment CALIXTO’99 in Romania, Geophys Res. Abst. 3:SE1.02.

Martin, M., F. Wenzel and the CALIXTO Working Group (2006). High resolution teleseismic body wave tomography beneath SE Romania, II. Imaging of a slab detachment scenario, Geophys. J. Int., 164, 579- 595.

Martinez-Garzón, P., G. Kwiatek, M. Ickrath and M. Bohnhoff (2014). MSATSI: A MATLAB- Package for Stress Inversion Combining Solid Classic Methodology, a New Simplified User-Handling, and a Visualization Tool, 


\section{Stress field pattern in the Vrancea zone}

Seismol. Res. Lett., 85, 4, 896-904.

Martinez-Garzón, P., Y. Ben-Zion, N. Abolfathian, G. Kwiatek and M. Bohnhoff (2016). A refined methodology for stress inversions of earthquake focal mechanisms, J. Geophys. Res., Solid Earth, 121, doi:10.1002/2016JB013493.

Matenco, L., C. Krézsek, S. Merten, S. Schmid, S. Cloetingh and P. Andriessen (2010). Characteristics of collisional orogens with low topographic build-up: an example from the Carpathians, Terra Nova, 22, 155-165.

Michael, A.J. (1984). Determination of stress from slip data: Faults and folds, J. Geophys. Res., 89, B13, 11517-11526.

Michael, A.J. (1987). Use of focal mechanisms to determine tectonic stress tensor: a control study, J. Geophys. Res., 92, 357-368.

Müller, B., O. Heidbach, M. Negut, B. Sperner and T. Buchmann (2010). Attached or not attached - how crustal stress observations contribute the intermediate depth seismicity of Vrancea, Tectonophysics, 482, 139-149.

Oncescu, M.C. (1984). Deep structure of the Vrancea region, Romania, inferred from simultaneous inversion for hypocenters and 3-D velocity structure, Annales Geophysicae, 2, 23-28.

Oncescu, M.C. (1987). On the stress tensor in Vrancea region, J. Geophys., 62, 1, 62-65.

Oncescu, M.C. and C.I. Trifu (1987). Depth variation of the moment tensor principal axes in Vrancea (Romania) seismic region, Ann. Geophysicae, 5B, 149-154.

Oncescu, M.C. and K.P. Bonjer (1997). A note on the depth recurrence and strain release of large intermediate Vrancea earthquakes, Tectonophysics, 272, 291-302.

Oncescu, M.C., V.I. Mârza, M. Rizescu and M. Popa (1999). The Romanian earthquake catalogue between 984-1997, in Vrancea Earthquakes: Tectonics, Hazard and Risk Mitigation (Eds. F. Wenzel, D. Lungu, O. Novak), Kluwer Academic Publishers, 43-47.

Pavel F., R. Vacareanu, J. Douglas, M. Radulian, C.O. Cioflan, A.H. Barbat (2016). An Updated Probabilistic Seismic Hazard Assessment for Romania and Comparison with the Approach and Outcomes of the SHARE Project, Pure Appl. Geophys., 173, 6,1881-1905.

Prieto, G.A., G.C. Beroza, S.A. Barrett, G.A. Lopez and M. Florez (2012). Earthquake nests as natural laboratories for the study of intermediate-depth earthquake mechanics, Tectonophysics, 570, 42-56, doi:10.1016/j.tecto.2012.07.019.

Pondrelli, S. and A. Morelli (2008). Seismic strain and stress field studies in Italy before and after the Umbria-Marche seismic sequence: a review, Ann. Geophys., 51, 2/3, https://doi.org/10.4401/ag-4446.

Popescu, E. and M. Radulian (2001). Source characteristics of the seismic sequences in the Eastern Carpathians foredeep region (Romania), Tectonophysics, 338, 325-337.

Popescu, E., C. Neagoe, M. Rogozea, I.A. Moldovan, F. Borleanu and M. Radulian (2011). Source parameters for the earthquake sequence occurred in the Ramnicu Sarat area (Romania) in November-December 2007, Rom. Journ. Phys., 56, 265-278.

Radulian, M., N. Mândrescu, E. Popescu, A. Utale and G. F. Panza (1999). Seismic activity and stress field in Romania, Rom. Journ. Phys., 44, 1051-1069.

Radulian, M., N. Mandrescu, E. Popescu, A. Utale and G. F. Panza (2000). Characterization of Romanian seismic zones, in Seismic Hazard of the Circum-Pannonian Region (Eds. G. F. Panza, M. Radulian, C. I. Trifu), Pure Appl. Geophys., 157, 57-77.

Radulian, M., E. Popescu, A. Bala and A. Utale (2002). Catalog of fault plane solutions for the earthquakes occurred on the Romanian territory, Rom. Jour. Phys., 47, 663-685.

Radulian, M. (2014). Mechanisms of Earthquakes in Vrancea, in Encyclopedia of Earthquake Engineering (Eds. M. Beer, E. Patelli, I. Kougioumtzoglou and I. Siu-Kui Au). Springer-Verlag, Berlin Heidelberg, doi:10.1007/9783-642-36197-5_302_1.

Radulian, M., A. Bala, E. Popescu and D. Toma-Danila (2018). Earthquake mechanism and characterization of seismogenic zones in south-eastern part of Romania, Ann. Geophys., 61, 1, SE108, doi:10.4401/ag-7443.

Radulian, M., A. Bala, L. Ardeleanu, D. Toma-Danila, L. Petrescu and E. Popescu (2019). Revised catalogue of earthquake mechanisms for the events occurred in Romania until the end of twentieth century: REFMC, Acta Geodaetica et Geophysica, 54, 3-18.

Radulian M., A. Bala, D. Toma-Danila (2020). REFMC 1929 - 2012 (Romanian Earthquake Focal Mechanism Catalogue). Mendeley Data, V3, doi: 10.17632/mykkx4gygy.3

Raileanu, V., C. Dinu, L. Ardeleanu, M. Diaconescu, E. Popescu, E. and A. Bala (2009). Crustal seismicity and associated 


\section{Andrei Bala et al.}

fault systems in Romania, in Proceedings of the 27-th ECGS Workshop: Seismicity Patterns in the Euro-Med Region, in Cahiers du Centre Européen de Géodynamique et de Sismologie, 153-160.

Raykova, R.B. and G.F. Panza (2006). Surface waves tomography and non-linear inversion in the southeast Carpathians, Phys. Earth Planet. Inter., 157, 164-180.

Protopopova, V.N. and E.A. Botev (2019). Evaluation and comparative analysis of stress and deformations in seismic hazard zones in Bulgaria and adjacent lands, Ann. Geophys., 63, 2, SE224, doi:10.4401/ag-8125.

Săndulescu, M. (1984). Geotectonics of Romania (in Romanian). Ed. Tehnică, Bucharest, Romania, 334.

Scherbaum, F., Kuehn, N., Zimmermann, B., (2009). WOLFRAM Demonstration Project "Earthquake focal mechanism", https://demonstrations.wolfram.com/EarthquakeFocalMechanism

Sperner, B., F.P. Lorenz, K.P. Bonjer, S. Hettel, B. Müller and F. Wenzel (2001). Slab break-off - abrupt cut or gradual detachment? New insights from the Vrancea Region (SE Carpathians, Romania), Terra Nova, 13, 172-179.

Szakács, A. and I. Seghedi (2013). The relevance of volcanic hazard in Romania: is there any?, Environ. Eng. Manag. J., 12, $125-135$.

Tondi, R., U. Achauer, M. Landes, R. Davi and L. Besutiu (2009). Unveiling seismic and density structure beneath the Vrancea seismogenic zone, Romania, J. Geophys. Res., 114, doi:10.1029/2008JB005992.

Townend, J. and M. D. Zoback (2000). How faulting keeps the crust strong, Geology, 28, 399-402.

Trifu, C-I. and M. Radulian (1994). Dynamics of a seismic regime: Vrancea - a case history, in Nonlinear Dynamics and Predictability of Geophysical Phenomena, Geophysical Monograph, 83, IUUG, 18 (Eds. A.M. Gabrielov and W.I. Newman). AGU, 43-53.

Vavryčuk, V., F. Bouchaala and T. Fischer (2013). High-resolution fault image from accurate locations and focal mechanisms of the 2008 swarm earthquakes in West Bohemia, Czech Republic, Tectonophysics, 590, 189 195.

Vavryčuk, V. (2014). Iterative joint inversion for stress and fault orientations from focal mechanisms, Geophys. J. Int., 199, 69-77.

Vavrycuk, V. (2015). Earthquake Mechanisms and Stress Field, in Encyclopedia of Earthquake Engineering, SpringerVerlag Berlin Heidelberg, doi:10.1007/978-3-642-36197-5_295-1.

Wallace, R.E. (1951). Geometry of Shearing Stress and Relation to Faulting, J. Geol., 59, 2, 118-130.

Wortel, R. and W. Spakman (2000). Subduction and slab detachment in the Mediterranean - Carpathian region, Science, 290, 1910-1917.

Zoback, M.L. (1992). First- and second-order patterns of stress in the lithosphere: the World Stress Map Project, J. Geophys. Res., 97, 11703-11728, https://doi.org/10.1029/92JB00132. 